\title{
Private Oppression: How Laws That Protect Privacy Can Lead to Oppression
}

\author{
Teri Dobbins Baxter
}

\section{INTRODUCTION}

Americans value privacy. Indeed, the notion that certain aspects of private life should be protected from government intrusion is incorporated into many provisions of the U.S. Constitution. Other federal laws and many state laws also protect the privacy of individuals and groups. Such rights as the freedom to practice one's chosen religion, the freedom to raise children in the manner deemed best by parents, and the right to marry are all privacy rights that are firmly established in the United States. However, these privacy rights are not absolute. Laws protecting children and other vulnerable individuals from abuse and neglect may trump privacy rights. But laws protecting the privacy of individuals or groups can make it difficult for government officials to enforce laws designed to protect those at risk.

These problems have been studied in the context of violence against women and children, although the focus has largely been on the status of children or the public versus private nature of family relationships. ${ }^{1}$ In contrast, this Article will identify laws that protect the privacy of individuals and groups (particularly families) as well as the laws designed to protect the health, dignity, and well-being of individuals.

\footnotetext{
Professor of Law, Saint Louis University. B.A., Duke University 1993; J.D., Duke University 1997. The author thanks Alicia Seibel for her valuable research and drafting assistance.

1. See, e.g., Martha Albertson Fineman \& Roxanne Mykitiuk, The Public Nature of PRIVATE VIOLENCE 3 (1994) ("Feminist activists and legal practitioners have ... developed legal definitions of private violence that better reflected women's experiences, pursued the prosecution and punishment of violent men, and helped women to empower themselves."); Elizabeth M. Schneider, The Violence of Privacy, 23 CONN. L. REV. 973, 974 (1990) ("This essay explores the ways in which concepts of privacy permit, encourage, and reinforce violence against women, focusing on the complex interrelationship between notations of 'public' and 'private' in our social understandings of woman-abuse."); Barbara Bennett Woodhouse, A Public Role in the Private Family: The Parental Rights and Responsibilities Act and the Politics of Child Protection and Education, 57 OHIO ST. L.J. 393, 393 (1996) ("address[ing] children's needs for responsible parenting and the continuing struggle to reach an appropriate balance between public and private roles in meeting these basic needs and in preparing children for citizenship").
} 
This Article will then examine how the enforcement of privacy laws can deprive individuals of the protection of other laws, including laws that guarantee individual rights and freedoms.

These issues will be viewed through the lens of the controversial case of the children taken into state custody from the Yearning for Zion Ranch ("YFZ Ranch" or "the Ranch") in Texas. Specifically, the Article will examine the allegations that led government authorities to intervene and remove the children from the Ranch and the court battle that resulted in the return of all but one child to their families. The Article will then explore the difficulties the government faces when such allegations are made against citizens of isolated communities who have little interaction with the larger American society. This Article will further demonstrate how privacy laws - originating in the U.S. Constitution, state constitutions, federal and state statutes, and common law doctrineswork together to make it possible for people to abuse or otherwise oppress others who are under their control or influence.

This Article is not intended as a judgment or condemnation of the YFZ residents or the Fundamentalist Church of Jesus Christ of Latter Day Saints ("FLDS Church"), nor is it a judgment of the guilt or innocence of any of those involved in the YFZ case. Indeed, in many respects, the YFZ Ranch is similar to every individual household in the United States. Every household enjoys a degree of privacy that cannot be intruded upon by the government absent extraordinary circumstances. However, the Ranch provides a degree of privacy that is not present for most people in larger, particularly urban, communities. The Ranch provides physical isolation of an entire, largely self-contained, multigenerational community. These unique features, in addition to the real conflict that arose when state officials took custody of hundreds of children that they believed were in danger of abuse at the YFZ Ranch, make it a useful vehicle for exploring the issues of privacy, freedom, and the potential for oppression.

Part II of this Article describes the YFZ Ranch and the events leading up to and following government officials' decision to remove hundreds of children from the Ranch and place them in state custody. Part III identifies provisions of the U.S. Constitution that protect privacy, particularly in the context of families and religious beliefs and practices. Part III also discusses the limits on the privacy rights conferred by various constitutional provisions. Part IV examines privacy rights conferred by state constitutions, statutes, and common law doctrines, as well as circumstances in which state interests override privacy rights. Part V reviews a bill introduced in the United States Senate to establish a federal polygamy task force and summarizes testimony at a Senate 
Hearing on crimes associated with polygamy. Part VI then describes how laws protecting privacy of all individuals can lead to the oppression of some vulnerable groups or individuals. Finally, Part VII explores ways in which government officials can prevent oppression and abuse without violating privacy rights, including regulating home schooling and establishing community outreach programs.

\section{YEARNING FOR ZION RANCH}

\section{A. Yearning for Zion and the FLDS Church Background}

The Yearning for Zion Ranch is a 1700 acre property located near the town of Eldorado in Schleicher County, Texas. ${ }^{2}$ A number of families associated with the FLDS Church live on the Ranch. ${ }^{3}$ The Church of Jesus Christ of Latter-day Saints (also known as the Mormon Church) previously embraced polygamy, but the practice was banned by the Church in $1890 .^{4}$ The FLDS Church-which separated from The Church of Jesus Christ of Latter-day Saints in the early twentieth century - still practices and advocates polygamy, even though it is illegal in all fifty states. ${ }^{5}$ Residents of the YFZ Ranch share these beliefs and allegedly practice polygamy, with men entering into "spiritual" marriages with multiple women. ${ }^{6}$ Young girls are alleged to have been "married" to adult (often much older) men when the girls are under the age of sixteen, the youngest age at which minors can be married in Texas without a court order. ${ }^{7}$ Moreover, girls as young as thirteen are alleged to have been impregnated by their "spiritual husbands." 8

\section{B. Government Removal of Yearning for Zion Children and Subsequent Court Orders}

In late March 2008, the Texas Department of Family and Protective Services (DFS) received a telephone call from a girl named Sarah who

2. In re Tex. Dep't of Family \& Protective Servs., 255 S.W.3d 613, 613 (Tex. 2008).

3. In re Steed, No. 03-08-00235-CV, 2008 WL 2132014, at*1 (Tex. App. May 22, 2008) (per curiam).

4. Bronson v. Swensen, 500 F.3d 1099, 1103 n.3 (10th Cir. 2007).

5. CAROLYN JESSOP \& LAURA PALMER, ESCAPE 18 (2007).

6. Because polygamy is illegal, the men cannot enter into more than one legal marriage. In re Tex. Dep't of Family \& Protective Servs., 255 S.W.3d at 613.

7. Id. at 616 (O'Neill, J., concurring in part and dissenting in part).

8. In re Steed, 2008 WL 2132014, at *2 n.5. 
claimed that she was being physically and sexually abused at the Ranch. ${ }^{9}$ DFS investigators and law enforcement officials entered the Ranch several days later in early April 2008. ${ }^{10}$ They interviewed adults and children and, without a court order, ultimately took possession of all of the girls and boys present at the Ranch-approximately 468 children. ${ }^{11}$

Under Texas law, DFS officials are allowed to take children into custody on an emergency basis if "the circumstances indicate a danger to the physical health and welfare of the children and the need for protection of the children is so urgent that immediate removal of the children from the home is necessary." ${ }^{\prime 2}$ DFS claimed that such a danger existed based upon the following evidence:

- Interviews with investigators revealed a pattern of girls reporting that "there was no age too young for girls to be married";

- Twenty females living at the ranch had become pregnant between the ages of thirteen and seventeen;

- Five of the twenty females identified as having become pregnant between the ages of thirteen and seventeen [were] alleged to be minors, the other fifteen are now adults;

- Of the five minors who became pregnant, four [were] seventeen, and one [was] sixteen, and all five [were] alleged to have become pregnant at the age of fifteen or sixteen;

- The Department's lead investigator was of the opinion that due to the "pervasive belief system" of the FLDS, the male children are groomed to be perpetrators of sexual abuse and the girls are raised to be victims of sexual abuse. ${ }^{13}$

According to DFS, the children were removed from the Ranch "under the theory that the ranch community was 'essentially one household comprised of extended family subgroups' with a single, common belief system and there was reason to believe that a child had been sexually abused in the ranch "household." 14

9. In re Tex. Dep't of Family \& Protective Servs., 255 S.W.3d at 613.

10. Id.

11. Id. at $613-14$. Sarah was never found. Id. at 614 .

12. In re Steed, 2008 WL 2132014 , at * 1 .

13. Id. at **1-2. Additionally, "[o]ne woman [was] alleged to have become pregnant at the age of thirteen." Id. at $* 2$ n.5.

14. Id. at $* 2$. 
DFS filed suits affecting the parent-child relationship (SAPCRs) and after an adversary hearing the district court issued temporary orders continuing DFS's custody of the children. ${ }^{15}$ Thirty-eight mothers filed petitions for writ of mandamus in the court of appeals seeking to have the district court's order vacated and their 126 children returned. ${ }^{16}$ The court of appeals found that the evidence presented at the district court hearing was "legally and factually insufficient to support the findings required" by Texas Family Code section 262.201 to allow DFS to maintain custody of the children. ${ }^{17}$ Because DFS failed to meet its burden of proof under the statute, the court of appeals directed the district court to vacate its orders granting sole managing conservatorship to DFS. ${ }^{18}$

DFS then filed a petition for writ of mandamus in the Texas Supreme Court. ${ }^{19}$ The court denied the petition, saying "[h]aving carefully examined the ... evidence before us, we are not inclined to disturb the court of appeals' decision. On the record before us, removal of the children was not warranted." 20 While the opinion was unanimous with respect to the male and prepubescent female children, several justices dissented from the opinion to the extent that it ordered the return of the pubescent female children. ${ }^{21}$

The dissenting justices found that the evidence was sufficient to satisfy the standard of section 262.201 that pubescent girls were at risk of sexual abuse. ${ }^{22}$ In particular, the expert witness called by the children's families testified that "the Fundamentalist Church of Jesus Christ of Latter Day Saints accepts the age of 'physical development' (that is, first menstruation) as the age of eligibility for 'marriage." 23 Additionally, a child psychologist testified that "the pregnancy of the underage children on the Ranch was the result of sexual abuse because children of the age of fourteen, fifteen, or sixteen are not sufficiently emotionally mature to enter a healthy consensual sexual relationship or a "marriage.",24

The dissenting opinion further pointed out that efforts to enable the children to return home-by seeking restraining orders against the

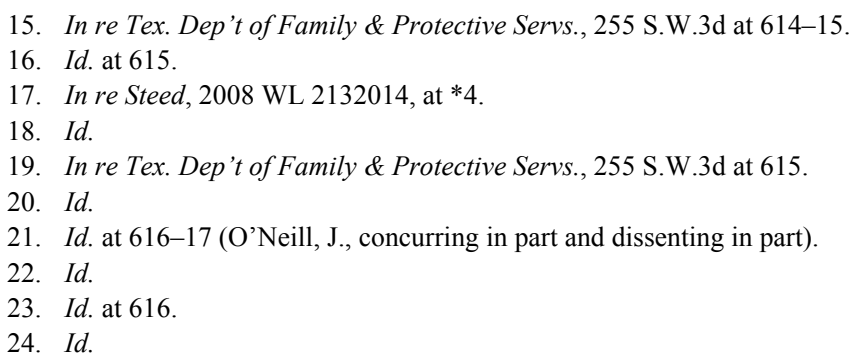


alleged perpetrators of the abuse-were thwarted by the mothers and children:

When the Department arrived at the YFZ Ranch, it was treated cordially and allowed access to children, but those children repeatedly pled "the Fifth" in response to questions about their identity, would not identify their birth-dates or parentage, refused to answer questions about who lived in their homes, and lied about their names - sometimes several times. Answers from parents were similarly inconsistent: one mother first claimed that four children were hers, and then later avowed that they were not. Furthermore, the Department arrived to discover that a shredder had been used to destroy documents just before its arrival.

Based on the evidence relating to pubescent girls, the dissent would have granted DFS's petition for mandamus. ${ }^{26}$

\section{Yearning for Zion Residents' Response}

It is important to note that the YFZ residents have disputed the allegations of sexual abuse, and in interviews after the raid, many residents denied any knowledge of sexual abuse or underage girls being married to older men. ${ }^{27}$ Moreover, the residents characterize their living arrangement as beneficial to the women and children of the families, with several women living with one man and the children of all of the women being raised together in a loving, supportive environment. ${ }^{28}$ Several women may be "married" to the same man, but the women insist that they have no objection to the arrangement. ${ }^{29}$ The women view themselves as mother to all of the children in the household and consider jealousy to be a sin or weakness that they must overcome in order to be like God. ${ }^{30}$ The children do not spend time in meaningless pursuits such as "play time," nor are fairy tales read to the children. ${ }^{31}$ Instead, the children work alongside the adults to grow food and maintain the households and community. ${ }^{32}$ Food is shared among all households and

25. Id. at $617-18$.

26. Id. at 618 .

27. The Oprah Winfrey Show: Oprah Goes Inside the Yearning for Zion Polygamist Ranch (ABC television broadcast Mar. 30, 2009).

28. Id.

29. Id.

30. Id.

31. Id.

32. Id. 
goods are available to all in need at no cost. ${ }^{33}$ Daily worship is also an integral part of everyday life. ${ }^{34}$

The residents view the Ranch as a safe environment where everyone works and strives to be like Christ. ${ }^{35}$ In their view, being removed from the violence and corruption of the larger society protects the women and children instead of harming or oppressing them. ${ }^{36}$ The raid by government officials and the emotional devastation that resulted for the families seemed to reinforce the view among residents that the government causes harm instead of preventing it. ${ }^{37}$ One woman who was taken from the Ranch when she was fourteen - because her mother feared the girl was about to be married to an older man-returned to the Ranch shortly after her eighteenth birthday, preferring the life on the Ranch to the outside world. ${ }^{38}$

\section{PRIVACY Rights ProteCted By the U.S. Constitution}

Privacy rights are protected by a variety of sources, with the U.S. Constitution being the preeminent source. While the Constitution does not refer explicitly to privacy, several provisions, including the First, Fourth, Ninth, and Fourteenth Amendments, have been interpreted as protecting privacy rights in various degrees and contexts.

\section{A. First Amendment Protection}

\section{Free Exercise Clause}

The First Amendment to the U.S. Constitution states in part: "Congress shall make no law respecting an establishment of religion, or prohibiting the free exercise thereof...., 39 These provisions, also known as the "Free Exercise Clause" and the "Establishment Clause," prevent the government from regulating religious beliefs or doctrines. ${ }^{40}$ Thus, the government may neither compel nor punish particular religious

\footnotetext{
33. Id.

34. $I d$.

35. $I d$.

36. Id.

37. $I d$.

38. Id. The woman, named Betty Jessop, is the daughter of Carolyn Jessop, co-author of ESCAPE. See supra note 5. Carolyn Jessop's Senate testimony criticizing the FLDS Church is discussed infra Part V.B.

39. U.S. CONST. amend. I.

40. Employment Div., Dep't of Human Res. of Or. v. Smith, 494 U.S. 872, 877-78 (1990).
} 
doctrine. ${ }^{41}$ Nor may it impose burdens on specific religious groups on the basis of their beliefs. ${ }^{42}$

The state may only intrude upon or limit religious liberty if "it is essential to accomplish an overriding governmental interest." Consequently, religious beliefs will be accommodated by the government unless restriction is necessary for the common good. ${ }^{44}$ In the past, the government has accommodated, among many others, a religious group who refused to send their children to school because it violated their religious beliefs, ${ }^{45}$ a group who employed animal sacrifice as part of their religious ceremonies, ${ }^{46}$ and a student whose religious beliefs were violated by a requirement that she utter certain words as part of assignments in a state university's theater program. ${ }^{47}$ In each case, courts found no government interest sufficiently compelling to overcome the right to free exercise of religion. ${ }^{48}$

In the landmark case of Employment Division, Department of Human Resources of Oregon v. Smith, the Supreme Court noted that in prior decisions it had applied a balancing test when parties sought exemption from generally applicable laws. ${ }^{49}$ Under that test, "governmental actions that substantially burden a religious practice must be justified by a compelling governmental interest." ${ }^{\text {"50 }}$ However, in Smith, the Court changed its position and concluded that the test is inapplicable to such challenges. "The government's ability to enforce generally applicable prohibitions of socially harmful conduct, like its ability to carry out other

41. See id.

42. Id. at 877. "The government may not compel affirmation of religious belief, punish the expression of religious doctrines it believes to be false, impose special disabilities on the basis of religious views or religious status, or lend its power to one or the other side in controversies over religious authority or dogma." Id. (citations omitted).

43. United States v. Lee, 455 U.S. 252, 257-58 (1982). This standard has become known as the strict scrutiny test. See, e.g., Church of the Lukumi Babalu Aye, Inc. v. City of Hialeah, 508 U.S. 520, 546 (1993) ("A law burdening religious practice that is not neutral or not of general application must undergo the most rigorous of scrutiny.... A law that targets religious conduct for distinctive treatment or advances legitimate governmental interests only against conduct with a religious motivation will survive strict scrutiny only in rare cases.").

44. Lee, 455 U.S. at 259.

45. Wisconsin v. Yoder, 406 U.S. 205, 207, 236 (1972) (members of Amish religion).

46. Church of the Lukumi Babalu Aye, 508 U.S. at 524 (members of Santeria religion).

47. Axson-Flynn v. Johnson, 356 F.3d 1277, 1280-81 (10th Cir. 2004) (member of The Church of Jesus Christ of Latter-day Saints).

48. Church of the Lukumi Babalu Aye, 508 U.S. at 546; Yoder, 406 U.S. at 233-34; AxsonFlynn, 356 F.3d at 1295.

49. Employment Div., Dep’t of Human Res. of Or. v. Smith, 494 U.S. 872, 883 (1990).

50. Id.

51. Id. at 885 . 
aspects of public policy, 'cannot depend on measuring the effects of a governmental action on a religious objector's spiritual development." ",52

Congress responded to this decision by passing the Religious Freedom Restoration Act of 1993 (RFRA). ${ }^{53}$ The Act states that "[g]overnment shall not substantially burden a person's exercise of religion even if the burden results from a rule of general applicability, except as provided in subsection (b)." ${ }^{, 54}$ The exceptions allow the burden if it "(1) is in furtherance of a compelling governmental interest," and (2) the government has employed the least restrictive means of furthering that interest. ${ }^{55}$ Thus, Congress sought to reinstate the compelling interest test that the Supreme Court rejected in Smith. ${ }^{56}$

Congress's effort was only partially successful. In City of Boerne v. Flores, the Supreme Court held that Congress exceeded its enforcement authority under the Fourteenth Amendment in enacting RFRA, at least insofar as it applied to the states. ${ }^{57}$ The statute-and the compelling interest test included therein-remains effective and binding on the federal government. ${ }^{58}$ Consequently, a generally applicable law that burdens the free exercise of religion does not violate the First Amendment, but if it is a federal law, it may violate RFRA. The residents of the YFZ Ranch, therefore, cannot rely on the Free Exercise Clause to exempt them from generally applicable state laws even if those laws conflict with their sincerely held religious beliefs. ${ }^{59}$

\section{Freedom of Intimate Association and Freedom of Expressive Association}

Supreme Court decisions have recognized that the First Amendment to the U.S. Constitution protects freedom of association in two different

52. Id. (quoting Lyng v. Nw. Indian Cemetery Protective Ass'n, 485 U.S. 439, 451 (1988)).

53. 42 U.S.C. $\S 2000 \mathrm{bb}(2006)$.

54. Id. § 2000bb-1(a).

55. Id. $\S 2000 \mathrm{bb}-1(\mathrm{~b})$

56. Id. $\S 2000 \mathrm{bb}(\mathrm{a})$.

57. City of Boerne v. Flores, 521 U.S. 507, 536 (1997). "Broad as the power of Congress is under the Enforcement Clause of the Fourteenth Amendment, RFRA contradicts vital principles necessary to maintain separation of powers and the federal balance." Id.

58. See Gonzales v. O Centro Espírita Beneficente Uniao do Vegetal, 546 U.S. 418, 439 (2006) (applying RFRA to case challenging the federal Controlled Substances Act which members of a religious sect claimed burdened the exercise of their religion).

59. They may, however, rely on a state law that is substantially similar to RFRA that was passed in 1999. See, e.g., Tex. Civ. Prac. \& Rem. Code AnN. § 110.003 (Vernon 2005); see discussion infra Part IV.B. 
contexts. $^{60}$ First, "the Court has concluded that choices to enter into and maintain certain intimate human relationships must be secured against undue intrusion by the State because of the role of such relationships in safeguarding the individual freedom that is central to our constitutional scheme." 61 This has been termed "freedom of intimate association.",62 The Court has not attempted to define precisely which relationships receive this constitutional protection, but it has noted that "certain kinds of personal bonds have played a critical role in the culture and traditions of the Nation," 63 and those relationships reflect "the realization that individuals draw much of their emotional enrichment from close ties with others." 64

Still, not every personal relationship is protected. Affiliations that have been recognized as worthy of constitutional protection include those involved in the creation and sustenance of a family or marriage, the raising and education of children, and cohabitation with relatives. ${ }^{65}$ The Court noted that these family relationships are distinguished by "relative smallness, a high degree of selectivity in decisions to begin and maintain the affiliation, and seclusion from others in critical aspects of the relationship." qualities are likely to be protected by the freedom of intimate association guarantee of the First Amendment. ${ }^{67}$

The second category of freedom of association is called "freedom of expressive association." 68 This kind of association refers to "a right to associate for the purpose of engaging in those activities protected by the First Amendment-speech, assembly, petition for the redress of grievances, and the exercise of religion." others in pursuit of a wide variety of political, social, economic, educational, religious, and cultural ends" is implicit in the right to engage in activities protected by the First Amendment. ${ }^{70}$

\footnotetext{
60. Roberts v. U.S. Jaycees, 468 U.S. 609, 617 (1984).

61. Id. at $617-18$.

62. Id. at 618 .

63. Id. at $618-19$.

64. Id. at 619 .

65. Id. (citing Zablocki v. Redhail, 434 U.S. 374, 383-86 (1978); Carey v. Population Servs. Int'l, 431 U.S. 678, 684-86 (1977); Smith v. Org. of Foster Families for Equal. \& Reform, 431 U.S. 816, 844 (1977); Moore v. City of E. Cleveland, Ohio, 431 U.S. 494, 503-04 (1977)).

66. Id. at 620 .

67. Id. In the Jaycees case, the Court held that membership in the Jaycees was not within the category of relationships protected by the Constitution. Id. at 620-21.

68. Id. at 618 .

69. Id.

70. Id. at 622 .
} 
Neither the freedom of intimate association nor the freedom of expressive association is absolute. However, because both are fundamental rights, ${ }^{71}$ government interference is subject to strict scrutiny. ${ }^{72}$ A party's freedom of association may only be infringed upon if justified by a compelling state interest. ${ }^{73}$ Moreover, the state must show that the interest cannot be achieved through significantly less restrictive means. $^{74}$

With respect to the YFZ residents, the freedom of intimate association certainly applies to their family relationships, marriages, the desire to raise and educate their children consistent with their religious beliefs, and the choice to live with other family members. Additionally, the YFZ residents have a protected right of expressive association to the extent that they associate for the purpose of engaging in activities protected by the First Amendment. In particular, they have a right to associate for the purpose of exercising their religion and pursuing social and educational goals. Living together in a community, worshiping together, and educating their children in religious schools are all protected forms of expressive association. The State of Texas cannot infringe upon these rights unless justified by a compelling state interest that cannot be achieved through less restrictive means.

\section{B. Limits on First Amendment Protection}

1. Freedom of Religion and Family Privacy Yield to the Interest in Protecting Minors from Abuse and Neglect

While the U.S. Constitution guarantees parents a great deal of latitude in determining how to raise their children, their rights are somewhat limited when the child's physical health is at issue. While the Supreme Court has not expressly addressed the rights of parents to refuse potentially life-saving treatment for their children if the treatment violates the parents' or children's religious beliefs, state and lower federal courts facing the issue have held that court orders authorizing

71. La. Debating \& Literary Ass'n v. City of New Orleans, 42 F.3d 1483, 1498 (5th Cir. 1995).

72. Jaycees, 468 U.S. at 623.

73. Id.; see also La. Debating \& Literary Ass'n, 42 F.3d at 1498 (noting that freedom of intimate association is also subject to strict scrutiny which requires the government to show a compelling interest that "cannot be achieved through means significantly less restrictive of one's associational freedom").

74. Jaycees, 468 U.S. at 623 . In the Jaycees case, the Court held that Minnesota had a compelling interest in eradicating gender-based discrimination and that the interest justified infringement on the Jaycees' freedom of expressive association. Id. at 623-25. 
treatment over the parents' objections do not violate the parents' constitutional rights. ${ }^{75}$

In Jehovah's Witnesses v. King County Hospital Unit No. 1, a class consisting of adult and minor members of the Jehovah's Witnesses (an unincorporated religious association) and their governing agency argued that provisions of the Washington Juvenile Court Law were unconstitutional as applied to them. ${ }^{76}$ The plaintiffs' religious beliefs prohibited receiving blood transfusions. ${ }^{77}$ The provisions at issue defined "dependent child" to include a child "who is grossly and wilfully neglected as to medical care necessary for his well-being." ${ }^{\text {"78 }}$ The Juvenile Court was authorized under a separate provision to enter orders for the care of any such dependent child. ${ }^{79}$ The plaintiffs' complaint alleged that the defendant physicians, hospitals, superior court judges, and juvenile court employees invoked these provisions to obtain court orders to remove minor children of Jehovah's Witnesses from their parents' custody when the parents refused to give consent for blood transfusions for the children. ${ }^{80}$ The children become wards of the court, and the court then authorizes the blood transfusions over the parents' objections. $^{81}$

The plaintiffs alleged that the application of the Juvenile Court Law under such circumstances violated their constitutional rights. ${ }^{82}$ Specifically, they alleged violation of their First Amendment rights to freedom of association, free exercise of religion, and the Establishment Clause; denial of life, liberty, and property without due process of law in violation of the Fifth Amendment; denial of their right to family privacy in violation of the Ninth and Fourteenth Amendments; and denial of the

75. See, e.g., Jehovah's Witnesses v. King County Hosp. Unit No. 1, 278 F. Supp. 488, 505 (W.D. Wash. 1967) ("'Parents may be free to become martyrs themselves. But it does not follow they are free, in identical circumstances, to make martyrs of their children before they have reached the age of full and legal discretion when they can make that choice for themselves." (quoting Prince v. Massachusetts, 321 U.S. 158, 170 (1944))), aff'd, 390 U.S. 598 (1968); O.G. v. Baum, 790 S.W.2d 839, 840-41 (Tex. App. 1990) ("The parents' first and fourteenth amendment guarantee of religious freedom does not include the liberty to expose their child to ill health or death.”).

76. Jehovah's Witnesses, 278 F. Supp. at 499.

77. Id. at 502. "Plaintiffs believe and accept as authoritative and binding upon them the admonition of Almighty God Jehovah found in the Holy Bible commanding Christians to 'abstain from blood." Id. The plaintiffs also believed that blood transfusions were risky, of limited or no medical value, and that alternative means of treatment were always available that made transfusions unnecessary and unadvisable. Id. at 503.

78. Id. at 498 n.1 (quoting WASH. REV. CODE $\S 13.04 .010(12)$ ).

79. Id. (quoting WASH. REV. CODE $\S 13.04 .095$ ).

80. Id. at 500

81. Id.

82. Id. 
equal protection of the laws. ${ }^{83}$ The plaintiffs sought a declaration that the disputed provisions were unconstitutional and invalid as applied to them and sought to enjoin state judges and other government agents from declaring children of plaintiffs or members of the plaintiff class to be wards of the state under those provisions solely based on the parents' refusal to authorize blood transfusions on religious or medical grounds. ${ }^{84}$

The district court believed that the United States Supreme Court's holding in Prince $v$. Massachusetts was applicable to Jehovah's Witnesses. ${ }^{85}$ While acknowledging that the Supreme Court did not intend for the holding in Prince to be extended beyond its facts, the district court nevertheless believed that "it does lay the foundation, binding upon us, for the particular state intervention in the name of health and welfare which is here under review." district court referenced the following language in Prince: "The right to practice religion freely does not include liberty [to] expose... the child . . to ill health or death." ${ }^{, 87}$ In accordance with Prince, the district court held that the Juvenile Court Code was not invalid under the U.S. Constitution. ${ }^{88}$ The Supreme Court affirmed the decision in a one line per curiam opinion citing Prince. ${ }^{89}$

In Texas, courts have relied on the Family Code's sections that authorize government action to protect minors' health and safety when granting government officers or entities temporary custody of minors whose parents refuse to allow necessary medical treatment. ${ }^{90}$ In $O . G . v$. Baum, a sixteen-year-old minor had been seriously injured when he was hit by a train and needed surgery to try to save his right arm. ${ }^{91}$ In a sworn statement presented to the trial court, the minor's doctor stated that a blood transfusion might be necessary during the course of the

83. Id. at $500-01$.

84. Id. at 501 .

85. Id. at 504 .

86. Id.

87. Id. (quoting Prince v. Massachusetts, 321 U.S. 158, 166-67 (1944)).

88. Id. at 505. The district court further noted that both the Illinois Supreme Court and the New Jersey Supreme Court had similarly interpreted Prince in cases involving blood transfusions for minor children of Jehovah's Witnesses. Id.

89. Jehovah's Witnesses v. King County Hosp. Unit No. 1, 390 U.S. 598, 598 (1968) (per curiam).

90. See O.G. v. Baum, 790 S.W.2d 839, 840 (Tex. App. 1990). At the time of that decision, Chapter 17 of the Family Code authorized appointment of a temporary managing conservator of the minor. See id. That chapter was repealed and the relevant provisions are now contained in Chapter 262 of the Family Code. See TeX. FAM. CodE ANN. § 262.110 (2008).

91. Baum, 790 S.W.2d at 840 . 
surgery. ${ }^{92}$ The minor's parents refused to allow the transfusion and the minor signed a statement purporting to release the hospital and physicians from any liability to him as a result of not giving the transfusion. ${ }^{93}$ Child Protective Services (CPS) filed suit and was appointed temporary managing conservator for the minor. ${ }^{94}$ The sole ground for the appointment was the parents' refusal to allow the transfusion. ${ }^{95}$ The parents filed a petition for writ of mandamus, arguing that the trial court abused its discretion in entering the temporary conservatorship order because the order infringed upon the free exercise of their religion and their right to privacy as guaranteed by the U.S. and Texas constitutions and Texas common law. ${ }^{96}$

The court of appeals also cited Prince's statement limiting parents' First and Fourteenth Amendment rights when their children's lives are at stake. ${ }^{97}$ The court then noted that other courts addressing the constitutionality of court orders consenting to blood transfusions over the parents' religious objections have held that such orders do not violate the parents' constitutional rights. ${ }^{98}$ Moreover, no contrary authority with respect to the U.S. Constitution, Texas Constitution, or Texas common law was cited by the parents. ${ }^{99}$ Consequently, the court of appeals held that the trial court did not abuse its discretion in appointing CPS temporary managing conservator of the minor. ${ }^{100}$

While there were no allegations that the YFZ parents neglected to provide necessary medical care to their children, it is worth noting that the Texas authorities would be justified in taking custody of the children on the Ranch if there was evidence that medically necessary treatment was being withheld on religious grounds. Indeed, such allegations have been made by a former member of another FLDS Church community. ${ }^{101}$

92. Id.
93. Id.
94. Id.
95. Id.
96. Id.
97. Id. (citing Prince v. Massachusetts, 321 U.S. $158,166-67$ (1944)).

98. Id. at 841 (citing Jehovah's Witnesses v. King County Hosp. Unit No. 1, 278 F. Supp. 488, 505 (W.D. Wash. 1967), aff'd, 390 U.S. 598 (1968); Staelens v. Yake, 432 F. Supp. 834, 839 (N.D. Ill. 1977)).

99. Id.

100. Id.

101. JESSOP \& PALMER, supra note 5, at 230 ("[Warren Jeffs] began preaching that anyone who needed medical help to heal was a person of little faith. A person in harmony with God could heal him- or herself with fasting and prayer. Before I saw this play out in our own home, I knew of several people who nearly died and children who became severely ill before they were taken to the hospital as a last resort.”). 
2. Laws Advancing Compelling State Interests May Justify

Infringement on Freedom of Association

States can enforce laws that infringe on freedom of association if the infringement is justified by a compelling state interest, is unrelated to the suppression of ideas, and the interest cannot be achieved through significantly less restrictive means. ${ }^{102}$ In Roberts $v$. United States Jaycees, the national Jaycees organization alleged that the Minnesota Human Rights Act violated its members' freedom of association rights because the Act required the admission of women as members of its Minnesota chapters. ${ }^{103}$ The Court was persuaded that Minnesota had a compelling interest in eradicating discrimination against its female citizens and ensuring equal access to publicly available goods and services. ${ }^{104}$ Moreover, the State sought to advance these interests through the least restrictive means. ${ }^{105}$ "[E]ven if enforcement of the Act causes some incidental abridgment of the Jaycees' protected speech, that effect is no greater than is necessary to accomplish the State's legitimate purposes." 106

In Buckley v. Valeo, the Court addressed a First Amendment challenge to a federal law that imposed reporting and disclosure requirements on political parties. ${ }^{107}$ The Court found compelling governmental interests in: providing information about who has contributed to a candidate's campaign and how that money was spent; ${ }^{108}$ avoiding corruption and the appearance of corruption by publicizing large contributions and expenditures, ${ }^{109}$ and gathering information necessary to identify violations of contribution limits. ${ }^{110}$ The parties challenging the disclosure laws conceded, and the Court agreed, "that disclosure requirements - certainly in most applications - appear to be the least restrictive means of curbing the evils of campaign ignorance and corruption that Congress found to exist."111 However, the Court found a diminished state interest in the disclosure of contributions made

102. Roberts v. U.S. Jaycees, 468 U.S. 609, 623 (1984).

103. Id. at 615 .

104. Id. at 623 .

105. Id. at 626 .

106. Id. at 628 .

107. 424 U.S. 1, 6 (1976) (per curiam).

108. Id. at $66-67$

109. Id. at 67 .

110. Id. at $67-68$.

111. Id. at 68 . 
to minor candidates with little chance of winning an election. ${ }^{112}$ On the record in that case, the Court found that "the substantial public interest in disclosure identified by the legislative history of this Act outweighs the harm generally alleged."

Likewise, in United States v. Lee, the Court held that an Amish employer was not exempt from paying social security taxes even though the payment of such taxes violated his religious beliefs. ${ }^{114}$ The Court found that the governmental interest in the social security system was apparent in the variety of benefits available to all participants. ${ }^{15}$ The system relies upon mandatory participation by employers and employees in order to remain viable. ${ }^{116}$ "[T] $]$ he Government's interest in assuring mandatory and continuous participation in and contribution to the social security system is very high." 117 Moreover, accommodating the religious beliefs of individuals would be untenable: ${ }^{118}$

The tax system could not function if denominations were allowed to challenge the tax system because tax payments were spent in a manner that violates their religious belief. Because the broad public interest in maintaining a sound tax system is of such a high order, religious belief in conflict with the payment of taxes affords no basis for resisting the tax.

Congress had already provided an exemption for self-employed Amish and others whose religious beliefs forbade payment of social security taxes and the Court noted that this exemption demonstrated Congress's sensitivity to the rights afforded by the Free Exercise Clause and the religious beliefs of individuals. ${ }^{120}$ However, it noted that the exemption was limited to self-employed individuals, which created a narrow group of readily identifiable persons to whom the exemption would apply. ${ }^{121}$

\footnotetext{
112. Id. at 70

113. Id. at 72

114. 455 U.S. 252,260 (1982).

115. Id. at 258

116. Id.

117. Id. at $258-59$.

118. Id. at 259 .

119. Id. at 260 (citations omitted).

120. Id. at 260-61. Congress provided an exemption from the social security tax for selfemployed members of religious groups whose beliefs were violated by such payments if the individual met certain criteria, including a waiver of his or her right to all social security benefits and proof that the religious group made sufficient provision for its dependent members. Id. at 255-56 (citing 26 U.S.C. $\$ 1402(\mathrm{~g})$ ). However, the defendant in Lee employed several other employees and, therefore, he did not qualify for the exemption. Id. at 256.
}

121. Id. at 260 . 
Expanding the exemption to include employers would not only broaden the scope of the exemption tremendously, it would also impose the employer's religious beliefs on the employees. ${ }^{122}$ Consequently, the tax was held to be constitutional as applied to Lee. ${ }^{123}$

\section{Fourteenth Amendment Due Process Clause Protection and Its Limits}

1. Substantive Due Process Protects Against Undue Regulation of Families and Intimate Relationships

While the state has the authority to regulate in ways that affect families, ${ }^{124}$ the Supreme Court has consistently protected "the private realm of family life which the state cannot enter." 125 The Court has described the policy behind such protection:

These matters, involving the most intimate and personal choices a person may make in a lifetime, choices central to personal dignity and autonomy, are central to the liberty protected by the Fourteenth Amendment. At the heart of liberty is the right to define one's own concept of existence, of meaning, of the universe, and of the mystery of human life. Beliefs about these matters could not define the attributes of personhood were they formed under compulsion of the State.

Over the last hundred years, the Court has held that the Due Process Clause protects the right to make decisions relating to marriage, ${ }^{127}$ procreation, ${ }^{128}$ contraception, ${ }^{129}$ child rearing and education, ${ }^{130}$ and the right of adults to engage in consensual sexual acts in private. ${ }^{131}$

Of particular relevance to the YFZ case is parents' right to send their children to private or religious schools for their education. In Pierce $v$. Society of the Sisters of the Holy Names of Jesus and Mary, private and

122. Id. at 261

123. Id.

124. Moore v. City of E. Cleveland, Ohio, 431 U.S. 494, 499 (1977) ("Of course, the family is not beyond regulation.").

125. Prince v. Massachusetts, 321 U.S. 158, 166 (1944).

126. Planned Parenthood of Se. Pa. v. Casey, 505 U.S. 833, 851 (1992).

127. Loving v. Virginia, 388 U.S. 1, 12 (1967).

128. Roe v. Wade, 410 U.S. 113, 153-54 (1973).

129. Casey, 505 U.S. at 851; Eisenstadt v. Baird, 405 U.S. 438, 453-54 (1972); Griswold v. Connecticut, 381 U.S. 479, 485 (1965).

130. Pierce v. Soc'y of the Sisters of the Holy Names of Jesus \& Mary, 268 U.S. 510, 534-35 (1925); Meyer v. Nebraska, 262 U.S. 390, 399 (1923).

131. Lawrence v. Texas, 539 U.S. 558, 578 (2003) 
religious schools filed suit to challenge Oregon's Compulsory Education Act, which required parents to send all children between the ages of eight and sixteen to public schools. ${ }^{132}$ The plaintiffs alleged that the Act violated their Fourteenth Amendment rights. ${ }^{133}$ The Supreme Court did not question the state's power to regulate, supervise, inspect, and examine schools, teachers, and students; to require that all children of a certain age attend some school; or to require certain subjects be taught. ${ }^{134}$ However, the Court believed that the Act "unreasonably interferes with the liberty of parents and guardians to direct the upbringing and education of children under their control."

This right has been extended in many states to allow parents to teach their children at home instead of sending their children to public or private schools. In Texas, home schools are recognized as a type of private school, which is expressly allowed under the state compulsory education law. ${ }^{136}$ Thus, under Texas law, the YFZ parents have the right to home school their children. ${ }^{137}$

This privacy interest also limits the degree to which the state can prevent extended families from living together. In Moore v. City of East Cleveland, Ohio, the Court held that a city ordinance that prohibited certain members of an extended family from living in the same household violated the parties' substantive due process rights under the Fourteenth Amendment. ${ }^{138}$ In that case, Moore was convicted of violating a city housing ordinance when she allowed her grandson to move into her home. ${ }^{139}$ Moore's son and grandson (uncle and cousin to the second grandson) were already living with her at the time. ${ }^{140}$ Under the ordinance, occupancy of the house was limited to a single family. ${ }^{141}$ The term "family" was defined in a way that did not encompass the arrangement in Moore's household. ${ }^{142}$

The city claimed that the Court's decision in Village of Belle Terre $v$. Boraas $^{143}$ was controlling. ${ }^{144}$ In Belle Terre, the Court upheld an

132. Pierce, 268 U.S. at 529-32.

133. Id. at 533 .

134. Id. at 534 .

135. Id. at 534-35.

136. Tex. Educ. Agency v. Leeper, 893 S.W.2d 432, 443-44 (Tex. 1994).

137. See id.

138. Moore v. City of E. Cleveland, Ohio, 431 U.S. 494, 504-06 (1977).

139. Id. at 496-97.

140. Id. at 496 .

141. Id. at $495-96$.

142. Id. at 496 n.2.

143. 416 U.S. 1 (1974). 
ordinance restricting land use to single family dwellings. ${ }^{145}$ "Family" was defined to mean "one or more persons related by blood, adoption, or marriage, living and cooking together as a single housekeeping unit, exclusive of household servants." ${ }^{146}$ The plaintiffs were owners of a house that they leased to six unrelated students attending a nearby university. ${ }^{147}$ The plaintiffs were charged with violating the ordinance and filed suit under 42 U.S.C. $\S 1983$ alleging violation of their constitutional rights. ${ }^{148}$ The district court upheld the ordinance and the Second Circuit Court of Appeals reversed. ${ }^{149}$ The Supreme Court held that there was no constitutional violation. ${ }^{150}$ First, the Court found that no fundamental right such as voting, right of association, or right of privacy was involved. ${ }^{151}$ Next, it noted that when legislating with respect to social or economic issues, no equal protection violation will be found if the law is reasonable, not arbitrary, and bears a rational relationship to a legitimate state objective. ${ }^{152}$ Because the ordinance met that test, it did not infringe on the plaintiff's constitutional rights. ${ }^{153}$

The city of East Cleveland argued that the ordinance under which Moore was convicted should be upheld on the same grounds as those in Belle Terre. ${ }^{154}$ The Supreme Court disagreed. ${ }^{155}$ The Court believed that "one overriding factor sets this case apart from Belle Terre. The ordinance there affected only unrelated individuals." 156 Because the East Cleveland ordinance sought to regulate families, Belle Terre did not control. $^{157}$

The Court acknowledged that housing ordinances may be a valid means of advancing legitimate governmental interests, but noted that the

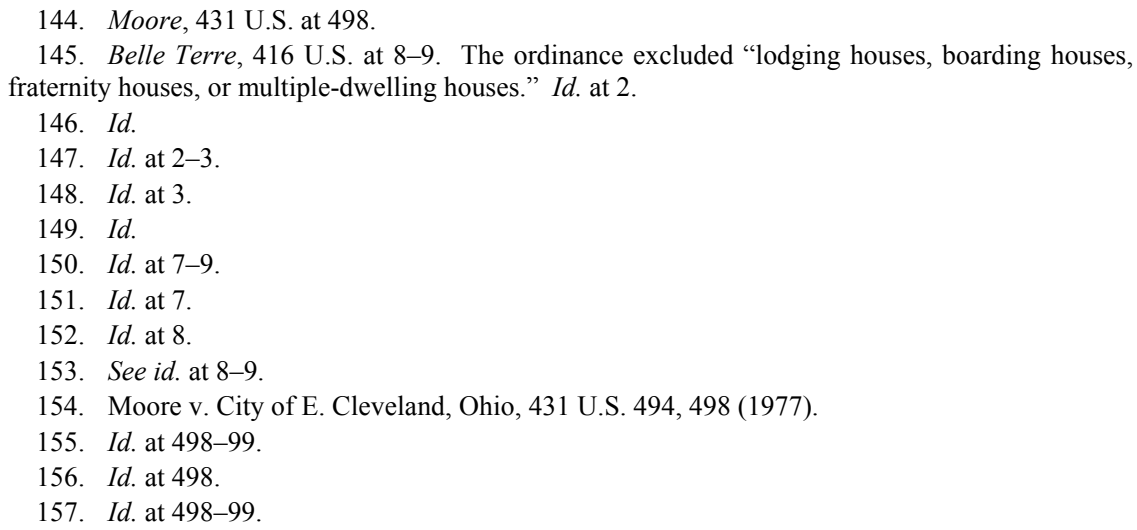


Court has previously held that the Due Process Clause of the Fourteenth Amendment protects freedom of personal choice in matters of family life. ${ }^{158}$ Although prior cases recognizing a due process right did not deal with housing choices or with rights for family members beyond the nuclear family, the Court noted that there is no precise formula for determining when the Due Process Clause applies and provides protection. ${ }^{159}$ Moreover, the family was recognized as an institution that is "deeply rooted in this Nation's history and tradition," 160 and that tradition has not been limited to nuclear families. ${ }^{161}$ Consequently, the Due Process Clause applied and protected the Moore family. ${ }^{162}$ The Court held that the ordinance in question had only a tenuous relation to the stated goals of controlling traffic and parking congestion and limiting the burden on the public school system. ${ }^{163}$ These objectives did not justify the burden on the Moore family, and the ordinance was held to be unconstitutional. ${ }^{164}$

The YFZ residents allegedly include several households with interrelated and extended families. ${ }^{165}$ The Due Process Clause of the Fourteenth Amendment protects the rights of those families and their choice to live together in the same household and would limit the State of Texas's ability to regulate or alter the families' living arrangements by passing housing or other zoning ordinances.

\section{Limits on Fourteenth Amendment Rights}

\section{a. Laws Prohibiting Sexual Conduct with Minors Do Not Violate Constitutional Rights}

While the right of adults to engage in private sexual conduct is protected by the Due Process Clause of the Fourteenth Amendment, ${ }^{166}$ no such right exists if adults seek to engage in sexual conduct with minors.

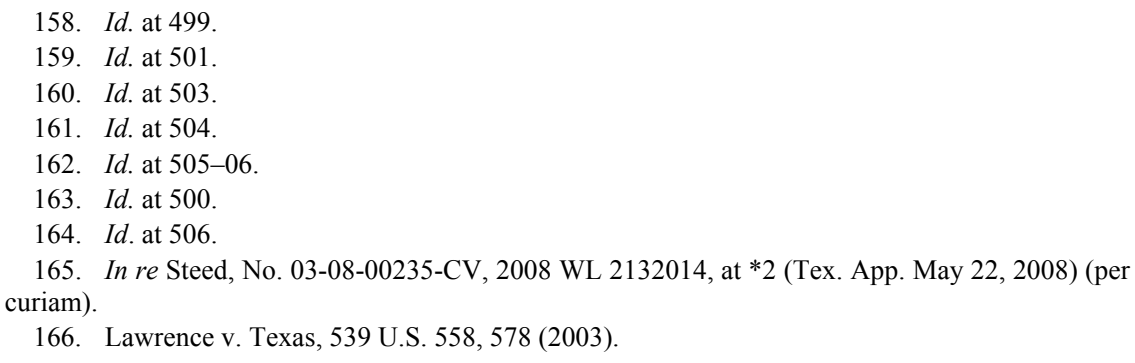


According to section 21.11 of the Texas Penal Code, "[a] person commits an offense if, with a child younger than 17 years of age, whether the child is of the same or opposite sex, the person engages in sexual contact with the child or causes the child to engage in sexual contact." 167 While this section only makes sexual contact a crime if the victim is not the perpetrator's spouse, ${ }^{168}$ in Texas a person must be sixteen years old in order to marry. ${ }^{169}$ Persons over sixteen but less than eighteen years of age must have parental consent in order to get married. ${ }^{170}$ It is a third degree felony for a person to "knowingly provide[] parental consent ... for an applicant who is younger than 16 years of age or who is presently married to a person other than the person the applicant desires to marry."171 Finally, while common law or "informal" marriages are recognized in Texas, ${ }^{172}$ persons under eighteen years of age may not be a party to an informal marriage. ${ }^{173}$

Among other accusations, adult male residents of the YFZ Ranch were alleged to have impregnated girls under the age of sixteen. ${ }^{174}$ Such sexual contact with the girls would qualify as indecency with a child, even if the contact was consensual. ${ }^{175}$ The accused men might try to argue that they are not guilty of any crime because they were married to the girls. ${ }^{176}$ However, because Texas law prohibits marriage of girls that young, any "marriage" involving the girls would be void. Consequently, the exception for spouses would be inapplicable.

167. Tex. Penal Code AnN. § 21.11(a)(1) (Vernon 2003). The section includes an affirmative defense for actors not more than three years older than the victim, who do not use duress, force, or a threat against the victim, who are not required to register as sex offenders, and have not had a reportable conviction or adjudication under this section. Id. $\S 21.11(\mathrm{~b})$.

168. Id. $\$ 21.11(\mathrm{~b}-1)$.

169. Tex. FAm. CodE ANN. § 2.102 (Vernon 2006).

170. Id. $\S 2.102(\mathrm{a})$.

171. Id. $\$ 2.102(\mathrm{~h})$.

172. Id. $\S 2.401$.

173. $I d . \S 2.401(\mathrm{c})(1)$. This section was amended in 1997 to add a minimum age requirement of eighteen for informal marriages. See Kingery v. Hintz, 124 S.W.3d 875, 877 n.2 (Tex. App. 2003) (noting that the purpose of the amendment was "to eliminate common-law marriage as a defense to statutory rape").

174. Dan Frosch, Texas Report Says 12 Girls at Sect Ranch Were Married, N.Y. TIMES, Dec. 24, 2008, at A17.

175. See Tex. Penal Code AnN. § 21.11(a) (Vernon 2003).

176. See Frosch, supra note 174 (stating that the underage girls were "spiritually" married to older men). 


\section{b. Polygamy is Illegal in Every State}

Polygamy is illegal in Texas ${ }^{177}$ and every other state. ${ }^{178}$ The Supreme Court rejected challenges to laws against polygamy on constitutional grounds as early as the late nineteenth century. ${ }^{179}$ The history of The Church of Jesus Christ of Latter-day Saints and the State of Utah has been central to the legal debate about polygamy. In 1890, The Church of Jesus Christ of Latter-day Saints - which had previously endorsed plural marriages - banned the practice. ${ }^{180}$ This was apparently done in an attempt to gain statehood for the territory of Utah. ${ }^{181}$ In 1894 , Congress passed the Utah Enabling Act, which required Utah to enact an "irrevocable" law protecting freedom of religion but forever banning polygamy or plural marriages. ${ }^{182}$ Utah complied, was made a state, and included the following provision in its constitution:

The following ordinance shall be irrevocable without the consent of the United States and the people of this State:

First: Perfect toleration of religious sentiment is guaranteed. No inhabitant of this State shall ever be molested in person or property on account of his or her mode of religious worship; but polygamous or plural marriages are forever prohibited. ${ }^{183}$

177. Tex. Penal Code AnN. § 25.01(a) (Vernon 2005):

(a) An individual commits an offense if:

(1) he is legally married and he:

(A) purports to marry or does marry a person other than his spouse in this state, or any other state or foreign country, under circumstances that would, but for the actor's prior marriage, constitute a marriage; or

(B) lives with a person other than his spouse in this state under the appearance of being married; or

(2) he knows that a married person other than his spouse is married and he:

(A) purports to marry or does marry that person in this state, or any other state or foreign country, under circumstances that would, but for the person's prior marriage, constitute a marriage; or

(B) lives with that person in this state under the appearance of being married.

An offense under this section is a third degree felony. Id. § 25.01(e).

178. Edward Stein, Past and Present Proposed Amendments to the United States Constitution Regarding Marriage, 82 WASH. U. L.Q. 611, 634 (2004) (citing HOMER H. ClARK, JR., THE LAW OF DOMESTIC RELATIONS IN THE UNITED STATES 64-65 (2d ed. 1988)).

179. See Reynolds v. United States, 98 U.S. 145, 166 (1878).

180. Bronson v. Swensen, 500 F.3d 1099, 1103 n.3 (10th Cir. 2007).

181. Brigham Daniels, Revitalizing Zion: Nineteenth-Century Mormonism and Today's Urban Sprawl, 28 J. LAND RESOURCES \& ENVTL. L. 257, 277 (2008).

182. Bronson, 500 F.3d at 1102.

183. UTAH CONST. art. III, $\S 1$. 
Because of the ban on polygamy, some members of The Church of Jesus Christ of Latter-day Saints split from the church and became known as the FLDS Church. ${ }^{184}$ Members of the FLDS Church believe in and practice polygamy. ${ }^{185}$ Many have challenged laws prohibiting plural marriages, arguing that such laws are unconstitutional. ${ }^{186}$

The Supreme Court first rejected that argument in Reynolds $v$. United States. ${ }^{187}$ The Court first concluded that a federal statute prohibiting bigamy was within the legislative power of Congress. ${ }^{188}$ Moreover, it held that the statute was constitutional and valid even as applied to individuals whose religion advocated plural marriages. ${ }^{189}$ Excusing violations of the law because the religious beliefs of the perpetrator were contrary to the law "would be to make the professed doctrines of religious belief superior to the law of the land, and in effect to permit every citizen to become a law unto himself."190 Later challenges have also failed. ${ }^{191}$

In Texas, not only is it a crime for a married person to marry another, it is also a crime for a married person to "live[] with a person other than his spouse ... under the appearance of being married."192 Thus, even if a man was legally married to one of the women, he could not legally be married to any other woman, nor could he live with another woman under the appearance of being married. This could be troubling for YFZ residents who did not legally marry but who live with more than one woman under the appearance of marriage.

\section{Fourth Amendment Protection from Unreasonable Search and Seizure}

The Fourth Amendment to the U.S. Constitution provides: "The right of the people to be secure in their persons, houses, papers, and effects,

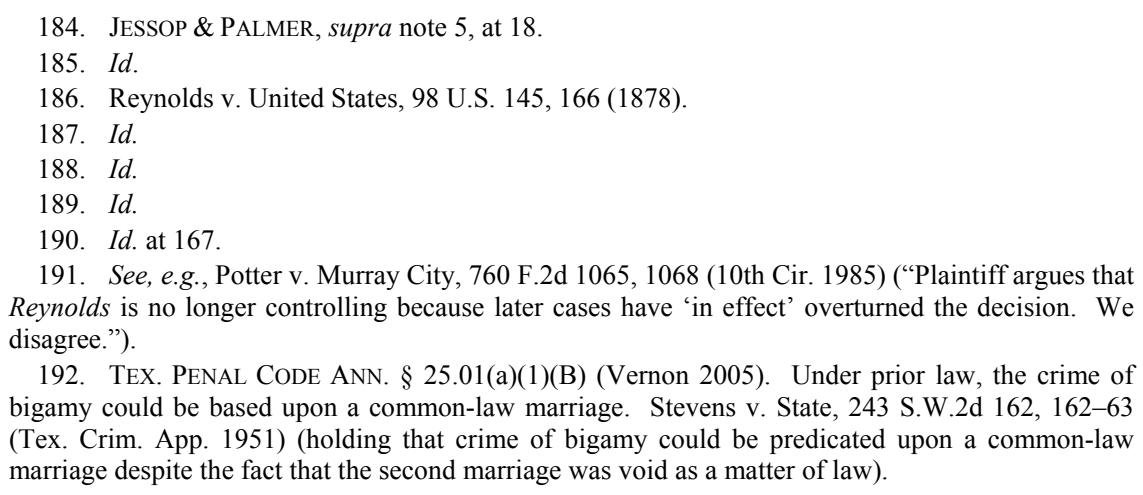
bigamy could be based upon a common-law marriage. Stevens v. State, 243 S.W.2d 162, 162-63 (Tex. Crim. App. 1951) (holding that crime of bigamy could be predicated upon a common-law marriage despite the fact that the second marriage was void as a matter of law). 
against unreasonable searches and seizures, shall not be violated . . ."193 The Fourth Amendment has been held to protect subjective expectations of privacy if society is prepared to recognize those expectations as reasonable. ${ }^{194}$ People are presumed to have an expectation of privacy in their homes, and courts have consistently protected that expectation. ${ }^{195}$ "With few exceptions, the question whether a warrantless search of a home is reasonable and hence constitutional must be answered no."196 Consequently, in most instances, in order for government officials to conduct a search of a person's home, the officials must obtain a warrant from a neutral magistrate supported by probable cause to believe that a crime has been or is being committed. ${ }^{197}$ However, warrantless searches may be reasonable if exigent circumstances exist that render the search reasonable. ${ }^{198}$

In the case of the YFZ Ranch, government officials could not arbitrarily enter onto the property or search the buildings, particularly the dwellings, without violating the Fourth Amendment. The physical barriers surrounding the property and the physical isolation from other dwellings provided further protection, since the activities of the residents were shielded from the "plain view" of non-residents. ${ }^{199}$ If government officials did receive evidence that provided probable cause of a crime, then a warrant could be issued and a search conducted in accordance with that warrant would not violate the Fourth Amendment.

Furthermore, police may enter and search a home without a warrant in order to render emergency aid or to protect an occupant from imminent harm; ${ }^{200}$ these would qualify as exigent circumstances that would obviate the need for a warrant. ${ }^{201}$ Consequently, government officials would be able to intervene and search the YFZ Ranch without a

193. U.S. CONST. amend. IV

194. Katz v. United States, 389 U.S. 347, 361 (1967) (Harlan, J., concurring).

195. Kyllo v. United States, 533 U.S. 27, 31 (2001) (“'At the very core' of the Fourth Amendment 'stands the right of a man to retreat into his own home and there be free from unreasonable governmental intrusion."” (quoting Silverman v. United States, 365 U.S. 505, 511 (1961))).

196. Id.

197. See, e.g., Griffin v. Wisconsin, 483 U.S. 868, 873 (1987) (noting that searches of homes usually require a warrant supported by probable cause).

198. Brigham City, Utah v. Stuart, 547 U.S. 398, 403 (2006).

199. The Supreme Court has held that visual observation of a home is not a search at all, thus the Fourth Amendment does not apply. Kyllo, 533 U.S. at 32. "The Fourth Amendment protection of the home has never been extended to require law enforcement officers to shield their eyes when passing by a home on public thoroughfares." California v. Ciraolo, 476 U.S. 207, 213 (1986).

200. Stuart, 547 U.S. at 403-04.

201. Id. 
warrant if such steps were necessary to protect a resident, particularly a child, from imminent harm.

\section{E. Ninth Amendment}

The Ninth Amendment states: "The enumeration in the Constitution, of certain rights, shall not be construed to deny or disparage others retained by the people."202 Some courts and scholars have identified the Ninth Amendment as a constitutional source of parental rights. ${ }^{203}$ The United States Supreme Court has recognized the integrity of the family as a fundamental right protected by the Ninth Amendment, ${ }^{204}$ and according to the Utah Supreme Court: "The rights inherent in family relationships-husband-wife, parent-child, and sibling-are the most obvious examples of rights retained by the people. They are 'natural,' 'intrinsic,' or 'prior' in the sense that our Constitutions presuppose them, as they presuppose the right to own and dispose of property."205 Despite these authorities, courts tend to rely on or cite the Ninth Amendment only in conjunction with other constitutional rights, perhaps because the precise contours and meaning of the Ninth Amendment have not been as clearly defined as those of other constitutional provisions. ${ }^{206}$ Still, at least with respect to parental rights, the Ninth Amendment provides another layer of constitutional protection.

\section{Privacy PROTECTION CONFERRED By STATE LAWS}

\section{A. State Constitutions That Specifically Include a Right of Privacy That Protects Against Intrusion by the Government}

Many state constitutions include provisions relating to religious and privacy rights. For example, the Texas Constitution states:

202. U.S. CONST. amend. IX

203. See, e.g., Troxel v. Granville, 530 U.S. 57, 91 (2000) (Scalia, J., dissenting) ("In my view, [the right of parents to direct the upbringing of their children] is among the "unalienable Rights'...."); In re J.P., 648 P.2d 1364, 1372-74 (Utah 1982) (citing Ninth Amendment as source of parental rights); Comment, People v. Bennett: Analytic Approaches to Recognizing a Fundamental Parental Right Under the Ninth Amendment, 1996 BYU L. ReV. 183, 189 (1996) (" $[\mathrm{T}]$ here is in fact a single expansive, fundamental right to direct the upbringing of one's children protected under the Ninth Amendment.").

204. Stanley v. Illinois, 405 U.S. 645, 651 (1972).

205. In re J.P., 648 P.2d at 1373.

206. See Comment, supra note 203, at 208 (noting the longstanding view that the Ninth Amendment poses the danger of "judicial freewheeling" and quoting Judge Bork's statement during his Senate confirmation hearing that the Ninth Amendment is an "ink blot"). 
All men have a natural and indefeasible right to worship Almighty God according to the dictates of their own consciences. No man shall be compelled to attend, erect or support any place of worship, or to maintain any ministry against his consent. No human authority ought, in any case whatever, to control or interfere with the rights of conscience in matters of religion, and no preference shall ever be given by law to any religious society or mode of worship. But it shall be the duty of the Legislature to pass such laws as may be necessary to protect equally every religious denomination in the peaceable enjoyment of its own mode of public worship. ${ }^{207}$

This provision grants affirmative rights with respect to religion that go well beyond any protection afforded by the U.S. Constitution. ${ }^{208}$ Consequently, the Texas Constitution may provide protection to the YFZ residents that the U.S. Constitution and federal statutes do not.

The California Constitution includes a specific provision protecting privacy. Under this provision, "[a]ll people are by nature free and independent and have inalienable rights. Among these are enjoying and defending life and liberty, acquiring, possessing, and protecting property, and pursuing and obtaining safety, happiness, and privacy."209 This explicit right to privacy has been interpreted by California courts to encompass greater privacy rights than those found in the U.S. Constitution. $^{210}$ In American Academy of Pediatrics v. Lungren, the California Supreme Court held that a state statute requiring pregnant minors to secure parental consent or judicial authorization before obtaining abortions violated the state constitutional right of privacy. ${ }^{211}$ The Court noted that "not only is the state constitutional right of privacy embodied in explicit constitutional language not present in the federal Constitution, but past California cases establish that, in many contexts, the scope and application of the state constitutional right of privacy is broader and more protective of privacy than the federal constitutional right of privacy as interpreted by the federal courts." 212

In contrast, the Pennsylvania Constitution uses language substantially similar to the U.S. Constitution, yet Pennsylvania courts have interpreted the Pennsylvania Constitution to provide greater privacy

\footnotetext{
207. TEX. CONST. art. I, § 6.

208. Waite v. Waite, 64 S.W.3d 217, 228 (Tex. App. 2001) ("The intention of the framers and ratifiers of the Texas Constitution, as evident in the plain meaning of the words they used, compels the conclusion that Article I, Section 6 provides broader protection of religious freedom than the First Amendment.").

209. CAL. CONST. art. I, § 1.

210. See Am. Acad. of Pediatrics v. Lungren, 940 P.2d 797, 808 (Cal. 1997).

211. Id. at 800 .

212. Id. at 808 .
} 
rights than the U.S. Constitution. ${ }^{213}$ The Pennsylvania Supreme Court has acknowledged broader state privacy rights not recognized in the federal context by granting automatic standing to assert search and seizure violations, rejecting the good faith exception to the warrant requirement, requiring warrants prior to placing pen registers, and finding that a sniff by a drug-sniffing dog constitutes a search. ${ }^{214}$

\section{B. State Religious Freedom Restoration Acts}

After the United States Supreme Court decided City of Boerne $v$. Flores in 1997, holding that the federal Religious Freedom Restoration Act could not be applied to the states, ${ }^{215}$ several states, including Texas, passed similar acts that apply to state law. ${ }^{216}$ In Texas, the statute states:

(a) Subject to Subsection (b), a government agency may not substantially burden a person's free exercise of religion.

(b) Subsection (a) does not apply if the government agency demonstrates that the application of the burden to the person:

(1) is in furtherance of a compelling governmental interest; and

(2) is the least restrictive means of furthering that interest. ${ }^{217}$

This statute was enacted in 1999 and makes the compelling interest test applicable to Texas state laws. ${ }^{218}$ In fact, section 110.001 directs courts to "give weight to the interpretation of compelling interest in federal case

213. See, e.g., Commonwealth v. Jackson, 698 A.2d 571, 573 (Pa. 1997) ("The protection against unreasonable searches and seizures afforded by the Pennsylvania Constitution is broader than that under the federal Constitution."). Similarly, the Utah Constitution uses language that is nearly identical to the U.S. Constitution, but Utah courts have found that the Utah Constitution offers greater privacy than its federal counterpart. See, e.g., State v. Thompson, 810 P.2d 415, 417-18 (Utah 1991) (rejecting contrary federal Fourth Amendment precedent to hold that a depositor has a legitimate expectation of privacy in his bank records).

214. Seth F. Kreimer, The Right to Privacy in the Pennsylvania Constitution, 3 WidENER J. PUB. L. 77, 84-85 (1993).

215. City of Boerne v. Flores, 521 U.S. 507, 511 (1997).

216. Connecticut, Idaho, Illinois, Missouri, Oklahoma, and Texas have passed Religious Freedom Restoration Acts with language similar to the federal statute. CONN. GEN. STAT. ANN. $\S$ 52-571b(b) (West 2005); IdAHo CODE ANN. § 73-402 (2006); 775 ILl. Comp. Stat. ANN. 35/15 (West 2001); Mo. AnN. Stat. $\S \S 1.302,1.307$ (West Supp. 2009); OKLA. Stat. AnN. tit. 51, $\S 253$ (West 2008); TEX. CiV. PraC. \& ReM. CodE ANN. § 110.003 (Vernon 2005); Kimberly A. Yuracko, Education Off the Grid: Constitutional Constraints on Homeschooling, 96 CAL. L. REV. 123, 129 (2008).

217. Tex. Civ. PraC. \& ReM. Code ANn. § 110.003.

218. See id. 
law relating to the free exercise of religion clause of the First Amendment of the United States Constitution" when deciding whether the asserted interest is a compelling governmental interest. ${ }^{219}$ The Connecticut, Idaho, Illinois, Missouri, and Oklahoma statutes have similar language. 220

\section{Statutes Authorizing State Intervention in Family Relationships}

1. Taking Possession of Children Without the Consent of a Parent or Guardian

While the U.S. Constitution protects parents' rights with respect to the rearing of their children, those rights are not unlimited. Specifically, parents have no right to neglect or abuse their children. States are allowed and even required to intervene to protect children from their parents if the health, safety, or well-being of the child is in jeopardy. Thus, while parents are presumed to act in the best interests of their children and generally cannot be deprived of their right to raise their children as they see fit, if the government has evidence that the child is in danger, the state's interest in protecting the child trumps the parents' rights. $^{221}$

In the case of the YFZ children, Texas law prevents state officials from removing children from the custody of their parent or guardian except under very specific circumstances in which there is evidence that the health or safety of the child is in danger. ${ }^{222}$ In order for a court to issue an emergency order authorizing the government to take possession of a child, the court must find: (1) that a child's physical health or safety is in immediate danger, or that the child has been neglected or sexually abused; (2) that leaving the child in the home is contrary to the child's welfare; (3) there is no time for a full adversary hearing; and (4) reasonable efforts have been made, consistent with the circumstances and

219. Id. § 110.001 .

220. Yuracko, supra note 216, at 129.

221. See Prince v. Massachusetts, 321 U.S. 158, 166-67 (1944) ("But the family itself is not beyond regulation in the public interest, as against a claim of religious liberty. And neither rights of religion nor rights of parenthood are beyond limitation... . The right to practice religion freely does not include liberty to expose the community or the child to communicable disease or the latter to ill health or death." (citations omitted)).

222. See Tex. Fam. Code AnN. § 262.001 (Vernon 2002). Chapter 262 of the Texas Family Code is titled "Procedures in Suit by Governmental Entity to Protect Health and Safety of Child." See id. 
the safety of the child, to prevent or eliminate the need to remove the child from the home. ${ }^{223}$

A representative of the Department of Family and Protective Services, a law enforcement officer, or a juvenile probation officer may take possession of a child without a court order only if there is no time to obtain an order and the official has "personal knowledge of facts that would lead a person of ordinary prudence and caution to believe that there is an immediate danger to the physical health or safety of the child," to believe that the child has been a victim of sexual abuse, or to believe that the person with possession of the child is using a controlled substance and the use constitutes an immediate danger to the physical health or safety of the child. ${ }^{224}$

\section{Terminating the Parent-Child Relationship}

States also have authority to terminate the relationship between parents and their children, but only in the most extreme circumstances. ${ }^{225}$

223. Id. $\S 262.102(\mathrm{a})$.

224. Id. $\S 262.104$. The full text of the section reads as follows:

Taking Possession of a Child in Emergency Without a Court Order

(a) If there is no time to obtain a temporary restraining order or attachment before taking possession of a child consistent with the health and safety of that child, an authorized representative of the Department of Family and Protective Services, a law enforcement officer, or a juvenile probation officer may take possession of a child without a court order under the following conditions, only:

(1) on personal knowledge of facts that would lead a person of ordinary prudence and caution to believe that there is an immediate danger to the physical health or safety of the child;

(2) on information furnished by another that has been corroborated by personal knowledge of facts and all of which taken together would lead a person of ordinary prudence and caution to believe that there is an immediate danger to the physical health or safety of the child;

(3) on personal knowledge of facts that would lead a person of ordinary prudence and caution to believe that the child has been the victim of sexual abuse;

(4) on information furnished by another that has been corroborated by personal knowledge of facts and all of which taken together would lead a person of ordinary prudence and caution to believe that the child has been the victim of sexual abuse; or

(5) on information furnished by another that has been corroborated by personal knowledge of facts and all of which taken together would lead a person of ordinary prudence and caution to believe that the parent or person who has possession of the child is currently using a controlled substance as defined by Chapter 481, Health and Safety Code, and the use constitutes an immediate danger to the physical health or safety of the child.

Id. $\S 262.104(\mathrm{a})$.

225. E.g., Santosky v. Kramer, 455 U.S. 745, 747-48 (1982). 
The fundamental liberty interest of natural parents in the care, custody, and management of their child does not evaporate simply because they have not been model parents or have lost temporary custody of their child to the State. Even when blood relationships are strained, parents retain a vital interest in preventing the irretrievable destruction of their family life. If anything, persons faced with forced dissolution of their parental rights have a more critical need for procedural protections than do those resisting state intervention into ongoing family affairs. When the State moves to destroy weakened familial bonds, it must provide the parents with fundamentally fair procedures. ${ }^{226}$

Before a state can irrevocably terminate a person's parental rights, the Due Process Clause of the Fourteenth Amendment of the U.S. Constitution requires that the state prove its allegations of abuse or neglect with clear and convincing evidence. ${ }^{227}$ The Texas statute providing for termination of the parent-child relationship adopts the clear and convincing standard and allows for termination of parental rights only if the state can prove that the parent is guilty of one of the enumerated instances of abuse or neglect and that termination is in the best interests of the child. ${ }^{228}$ In cases in which the state seeks to terminate parental rights, indigent parents have the right to have counsel appointed to represent them in all critical stages of the proceedings. ${ }^{229}$

\section{Tort Laws Protecting Against Intrusion by Private Individuals}

\section{Privacy Torts}

The Restatement (Second) of Torts recognizes four different claims for invasion of privacy: (1) intrusion upon seclusion; (2) appropriation of name or likeness; (3) publicity given to private life; and (4) publicity

\footnotetext{
226. Id. at 753-54.

227. Id. at $747-48$.

228. TEX. FAM. CODE ANN. $\S 161.001$ (Vernon 2008). The statute authorizes the court to terminate the parent-child relationship if it finds clear and convincing evidence of abuse, neglect, or endangerment, including voluntarily leaving the child alone, endangering the physical or emotional well-being of the child, causing the failure of the child to be enrolled in school, or abandonment of the child. Id. The relationship can also be terminated if the parent engages in criminal conduct resulting in conviction and incarceration, if the parent causes the child to be born addicted to alcohol or a controlled substance, or is convicted of the murder of the child's other parent or of another child. Id. In all cases, the court must find that termination of the parent-child relationship is in the best interests of the child. $I d$.

229. Id. § 107.013(a)(1); see also In re M.S., 115 S.W.3d 534, 544 (Tex. 2003) (holding that the statutory right to counsel in parental rights cases embodies the right to effective assistance of counsel).
} 
placing person in false light. ${ }^{230}$ The intrusion tort allows recovery against one who intentionally intrudes "upon the solitude or seclusion of another or his private affairs or concerns ... if the intrusion would be highly offensive to a reasonable person." ${ }^{\text {231 }}$ A person commits the tort of appropriation if he "appropriates to his own use or benefit the name or likeness of another." ${ }^{232}$ Additionally, a person is subject to liability if that person publicized private information about another and "the matter publicized is of a kind that (a) would be highly offensive to a reasonable person, and (b) is not of legitimate concern to the public."233 Finally:

One who gives publicity to a matter concerning another that places the other before the public in a false light is subject to liability to the other for invasion of his privacy, if (a) the false light in which the other was placed would be highly offensive to a reasonable person, and (b) the actor had knowledge of or acted in reckless disregard as to the falsity of the publicized matter and the false light in which the other would be placed. ${ }^{234}$

Not all states recognize all four invasion of privacy claims, and the elements of each claim may vary by jurisdiction. Texas recognizes only three types of invasion of privacy: intrusion upon seclusion, public disclosure of private facts, and wrongful appropriation of name or likeness. ${ }^{235}$

\section{Trespass}

In Texas, trespass can be a crime and a tort. Criminal trespass requires proof that "(1) a person, (2) without effective consent, (3) enters or remains on the property or in a building of another, (4) knowingly, intentionally, or recklessly, (5) when he had notice that entry was forbidden or received notice to depart and failed to do so." ${ }^{, 236}$ The tort of trespass can be established merely by proving an unauthorized entry onto property. $^{237}$ "A trespass can be either by entry of a person on another's land or by causing or permitting a thing to cross the boundary of the

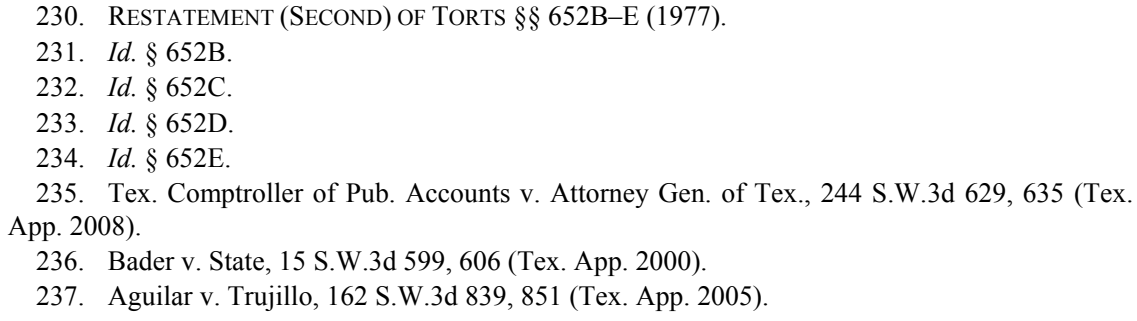


premises. Finally, a trespass may be committed on, beneath, or above the surface of the earth."238 Laws against trespass allow the YFZ residents to prevent private citizens as well as government officials from entering onto their property without permission. This contributes to the isolation of the residents and prevents contact with those in the larger community.

\section{CONGRESS's RESPONSE}

\section{A. Bill Introduced by Senator Harry Reid: "To establish a Federal Polygamy Task Force, to authorize assistance for victims of polygamy, and for other purposes ${ }^{\text {"239 }}$}

On July 23, 2008, Senator Harry Reid of Nevada introduced the "Victims of Polygamy Assistance Act of 2008." 240 The bill included the following findings: large polygamist communities exist in Arizona, Utah, and Nevada and are expanding into other states; the polygamous communities are controlled by organizations that "engage in widespread and systematic violations" of state and federal laws; those crimes include child abuse, domestic violence, welfare fraud, tax evasion, public corruption, witness tampering, and transporting victims across state lines; and state and local law enforcement would benefit from the assistance of the federal government, including enhanced collaboration and information-sharing among state and federal agencies. ${ }^{241}$ Moreover, the bill included a finding that polygamist organizations "isolate, control, manipulate, and threaten victims with retribution should they ever abandon the organization." 242 Consequently, victims of polygamist organizations have unique social service needs warranting federal assistance. $^{243}$

The bill provided for the establishment of a Federal Polygamy Task Force within the Department of Justice, which would coordinate federal efforts and collaborate with state officials "in the investigation and prosecution of criminal activities of polygamist organizations in both Federal and State Courts." 244 The Task Force would "consist of the

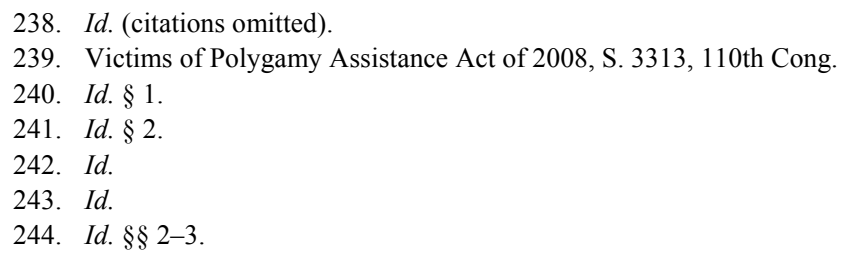


Deputy Attorney General, the United States attorneys from affected Federal judicial districts, representatives of the Federal Bureau of Investigation, the Internal Revenue Service, the Department of Labor, and the Department of Health and Human Services," and any other federal government officer that the Deputy Attorney General considers necessary to achieve the goals of the Task Force. ${ }^{245}$ The purposes of the Task Force are to:

(1) formulate effective responses to the unique set of crimes committed by polygamist organizations;

(2) establish partnerships with State and local law enforcement agencies to share relevant information and strengthen State and Federal efforts to combat crimes perpetrated by polygamist organizations;

(3) assist States by providing strategies and support for the protection of witnesses;

(4) track the criminal behavior of polygamist organizations that cross State and international borders; and

(5) ensure that local officials charged with protecting the public are not corrupted because of financial, family, or membership ties to a polygamist organization. ${ }^{246}$

The bill would also amend the Victims of Crime Act of 1984 by empowering the Director to make grants to develop and maintain programs for enforcing the rights of and providing social services for individuals victimized by polygamists. ${ }^{247}$ The bill provided that funds in the amount of \$2 million for fiscal year 2009 and \$2.5 million for the next four fiscal years would be appropriated to carry out these goals. ${ }^{248}$ Finally, the bill would amend the Omnibus Crime Control and Safe Streets Act of 1968 to grant \$2 million from the Attorney General to state and local governments to investigate and prosecute polygamist organizations. $^{249}$

\footnotetext{
245. Id. $\S 3(\mathrm{a})$.

246. Id. §3(b).

247. Id. $\S 4$.

248. Id.

249. Id. § 5 .
} 


\section{B. Senate Committee Hearing on "Crimes Associated with Polygamy: The Need for a Coordinated State and Federal Response"}

The Victims of Polygamy Assistance Act of 2008 was referred to the Senate Judiciary Committee and on July 24, 2008, the Committee held a hearing on "Crimes Associated with Polygamy: The Need for a Coordinated State and Federal Response." 250 Those testifying included the bill's sponsor, Senator Harry Reid; Gregory A. Brower, United States Attorney for the District of Nevada; Brett Tolman, United States Attorney for the District of Utah; Terry Goddard, Arizona Attorney General; Greg Abbott, Texas Attorney General; Stephen Singular, investigative journalist and author of non-fiction books; Daniel Fischer, dentist and former member of the FLDS Church; and Carolyn Jessop, former member of the FLDS Church and former wife of Merril Jessop, whom she alleged runs the YFZ Ranch. ${ }^{251}$

Carolyn Jessop testified before Congress about her "firsthand experiences of the systematic abuse and the disregard for the law within the FLDS which leads to the isolation of its most vulnerable individuals within any community-women and children, who live without the protection of laws that most Americans take for granted."252 Jessop escaped from the community in 2003 with her eight children, and she coauthored a book about her life in the community and her escape from it. ${ }^{253}$ In her testimony, Jessop noted that the community's cruel practices and disregard for the law lead to the isolation of women and children. ${ }^{254}$ Jessop condemned local law enforcement, nearly all of whom were FLDS members, for their indifference to domestic abuse and child labor law violations. ${ }^{255}$ Even though Jessop managed to escape, she expressed the apprehension she had felt at contacting government service agencies because she feared the legal consequences of being a former member of a polygamous community. ${ }^{256}$ Once Jessop did seek help, she found she did not qualify for the assistance she needed. ${ }^{257}$ According to Jessop, women leaving FLDS communities need physical, psychological, and emotional

250. Crimes Associated with Polygamy: The Need for a Coordinated State and Federal Response: Hearing Before the S. Comm. on the Judiciary, 110th Cong. I (2008) [hereinafter Hearing].

251. Id. at III.

252. Id. at 29 (statement of Carolyn Jessop, West Jordan, Utah).

253. See JESSOP \& PALMER, supra note 5.

254. Hearing, supra note 250, at 29 (statement of Carolyn Jessop, West Jordan, Utah).

255. Id. at $29-30$

256. Id. at 30 .

257. Id. at 31 . 
support, and she argued that the federal government needs to provide safe havens outside FLDS communities to support women who wish to leave in addition to ensuring that state and federal laws are enforced in FLDS communities. $^{258}$

Stephen Singular is an investigative journalist and nonfiction writer who had been studying Warren Jeffs and the FLDS Church since 2006, and he focused his prepared statement on tracing Jeffs's abusive practices and disregard for the legal system. ${ }^{259}$ According to Singular, Jeffs has ignored child labor laws, laws prohibiting minors to cross state lines for sexual purposes, and laws against bigamy and underage marriage. ${ }^{260}$ Singular's testimony indicated that women and girls were not Jeffs's only victims. ${ }^{261}$ Singular claimed that Jeffs regularly expelled rebellious young men out into the streets and failed to address genetic disorders caused by the community's inbreeding. ${ }^{262}$ Singular noted that sympathetic local law enforcement and hidden financial reserves helped Jeffs and the FLDS Church continue this criminal lifestyle, and Singular asserted that an investigation by those with subpoena power in conjunction with cooperative former FLDS members was the only way to know the full extent of the FLDS Church's crimes. ${ }^{263}$

Daniel Fischer, a former member of the FLDS Church and the cofounder of an organization to help expelled FLDS youth, testified as to his experience with the community. ${ }^{264}$ Fischer noted that FLDS members feel persecuted, that they are willing to sacrifice themselves and their families if their leader so directs, and that marriage and families are completely controlled by FLDS leadership. ${ }^{265}$ Fischer emphasized the damage to children and families caused by Jeffs's expulsion of men from the community and Jeffs's subsequent orders to their wives to remarry. ${ }^{266}$ Fischer urged Congress to take action to protect children from the illegal actions of the FLDS Church. ${ }^{267}$

Terry Goddard, the current Arizona Attorney General, submitted a written statement, which he summarized in his testimony before the

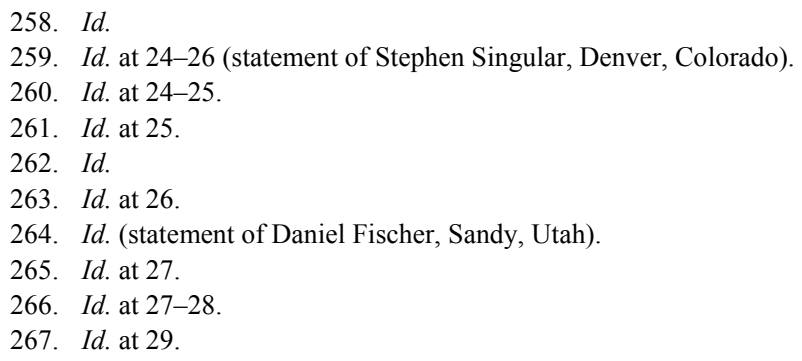


committee. ${ }^{268}$ In his statement, Goddard observed the public backlash created by early Arizona law enforcement raids on the fledgling FLDS Church community. ${ }^{269}$ As a result, law enforcement began to ignore these communities, residents became suspicious of law enforcement, and the leaders of the communities assumed more control over their followers. $^{270}$ In 2003, to combat these effects, Goddard and Utah Attorney General Mark Shurtleff formed a partnership to coordinate civil and criminal investigations and offer services for victims of child and domestic abuse. ${ }^{271}$ Goddard noted that these services, provided under the umbrella of the Safety Net Program, now include assistance from law enforcement agencies, local service agencies, advocacy groups, and members of the community. ${ }^{272}$

According to Goddard, one of this initiative's most significant accomplishments was the indictment of Warren Jeffs on child abuse charges in Arizona and Utah. ${ }^{273}$ Goddard noted that problems with law enforcement in the current FLDS Church communities of Colorado City and Hildale stem from local officer allegiance to Jeffs and Goddard's Office's limited state civil rights jurisdiction. ${ }^{274}$ Goddard suggested that the federal government or county sheriffs might easily assert authority over civil rights violations in FLDS Church communities, and he noted that coordination among local, state, and federal law enforcement agencies would be crucial to prosecute multi-jurisdictional crimes. ${ }^{275}$

Finally, Goddard mentioned that the closing of FLDS Church private schools following Jeffs's arrest and Jeffs's subsequent order forbidding

\footnotetext{
268. Id. at 11-12 (statement of Terry Goddard, Att'y Gen., State of Arizona).

269. Id. at 12 .

270. Id. As Mr. Goddard put it:

I have been intent on not repeating the heavy-handed mistakes of the past. Arizona badly executed a police raid in 1953 known as the "Short Creek raid" that took most of the children in the community into custody and made them wards of the State. And it had three long-term negative effects:

First, afterwards, governmental authorities were reluctant to do anything, to pay any attention to the area of Short Creek, soon renamed Colorado City, and Hildale in Utah Second, the residents of these communities became highly suspicious of Government at all levels. We found that victims of abuse feared the State more than their abuser. And, third, the leaders of the FLDS Church used the first two to increase their autocratic authority over their followers.
}

Id. The unfortunate similarities between the Short Creek raid and the raid on the YFZ Ranch are readily apparent.

271. Id.

272. Id. at $12-13$

273. Id. at 81 (written statement of Terry Goddard, Att'y Gen., State of Arizona).

274. Id.

275. Id. 
FLDS parents from enrolling their children in public schools were of particular concern. ${ }^{276}$ He noted that few parents had filed homeschooling affidavits and that there were reports that children were being sent to work. ${ }^{277}$ Nonetheless, Goddard asserted that the Safety Net agencies were providing "legal assistance, housing, counseling, education and other support to victims in need."278 Goddard mentioned other successes the Utah-Arizona partnership had achieved, including the development of a training curriculum to help professionals provide services to victims in polygamous communities, the establishment of a twenty-four-hour, toll-free helpline for victims, the passage of child bigamy statutes in Arizona and Utah, and the organization of town hall meetings to allow members of Colorado City and Hildale to converse with law enforcement leaders. ${ }^{279}$

\section{RESULTING OPPRESSION}

The laws protecting privacy leave the government unable to investigate or intervene without credible evidence that the law has been violated. ${ }^{280}$ Because the perpetrators are not likely to supply that information, the crime may go undetected and unpunished unless the victim or a third party does so. Yet there are many reasons why neither victims nor third parties will give the government the information necessary to allow intervention.

One reason is isolation. Those who are physically separated from the larger community may be unable to contact help when needed. Moreover, if the victim is isolated, there may not be any third-party witnesses who can intervene or call the authorities on the victim's behalf. ${ }^{281}$ A second obstacle is ignorance. Those who are unaware that they have rights that are being violated may not seek help. This may be the case because of isolation; if a person has lived all of his or her life in an isolated community, then those beliefs and values may be all that is known. He or she may have no concept of the rights and laws that

\footnotetext{
276. Id. at 82 .

277. Id.

278. Id

279. Id. at $82-84$

280. U.S. CONST. amend. IV; see discussion supra Part III.D.

281. JESSOP \& PALMER, supra note 5, at 13-14. "Our community was so isolated it was rare that we ever saw anyone from the outside. Most of my cousins only left the community to go shopping with their mothers and had almost no sense of the outside world." Id. "Even if a family knew there was severe abuse going on in another family, no one intervened. This was part of the religious doctrine that said no man had the right to interfere with another man's family." Id. at 37.
} 
protect them or that behavior they have always accepted is illegal. ${ }^{282}$ For immigrants, language barriers may leave them without an understanding of law or resources available to help. ${ }^{283}$ If their legal status is an issue, they may be afraid to report abuse for fear of being imprisoned or deported. $^{284}$ Moreover, their abuser may have control over their legal status.

Age may also play a role. The very young and very old may be unable to voice opposition, seek help, or even recognize abuse when it occurs. With respect to children, parents are empowered by law to make decisions that affect the future of their children. With respect to the elderly, they may be completely dependent upon others for their care and may be unable or unwilling to risk the consequences of angering or pressing charges against a caregiver, especially if the caregiver is a child or other relative. ${ }^{285}$

\section{VII.STRIKING THE RIGHT BALANCE}

\section{A. Laws Respecting Privacy Limit a Government's Ability to Protect Its Citizens}

Laws designed to protect citizens are limited in the sense that they require some evidence that illegal activity has occurred, is occurring, or will occur. Government officials are not authorized to monitor or interfere based solely on suspicion or disapproval of the lifestyle or beliefs of individuals. The Constitution, supplemented by state laws, gives people, particularly parents, the right to isolate themselves or live within an isolated community, thereby depriving outsiders or law enforcement of the opportunity to observe anything that would justify investigation or intervention. These privacy rights effectively ensure that some abuse, neglect, and oppression will go undetected and unpunished.

While it is possible to provide greater protection to children and other vulnerable populations, the protection would necessarily come at

282. "Violence toward children was incorporated into our belief system, and it was very common in the community to see a mother slap one of her children, sometimes very hard." Id. at 19-20. "We were taught that the government (which was wicked) would move into our community and try to kill every man, woman, and child." Id. at 24.

283. See Leslye E. Orloff et al., Battered Immigrant Women's Willingness to Call for Help and Police Response, 13 UCLA WOMEN's L.J. 43, 46 (2003).

284. Id. at 47.

285. Mary Twomey et al., From Behind Closed Doors: Shedding Light on Elder Abuse and Domestic Violence in Late Life, 6 J. CENTER FOR FAMS., CHILD. \& CTS. 73, 75 (2005) ("Ninety percent of all elder abuse is perpetrated by family members."). 
the expense of privacy. Indeed, many scholars, particularly feminists and child advocates, have criticized modern notions of family privacy that "can conceal, even foster, situations dangerous to the individuals who comprise the family unit." 286 Despite these critiques, the right to privacy, especially within the home and with respect to the rearing of children, is so deeply ingrained in American culture and is so deeply cherished by most parents that it is doubtful that many would be willing to give up those rights even if it meant saving some people from abuse or neglect.

For many, the rights of parents are not simply a matter of state law, but of religious beliefs. ${ }^{287}$ But even if the beliefs are not religiously based, the right of parents to raise their children without government interference is longstanding and deeply held and not likely to be easily eroded. In fact, in recent decades there has been a push to reassert and fortify parents' rights. ${ }^{288}$ In 1995, bills were sponsored in the United States House of Representatives and Senate with the stated goal of protecting "the fundamental right of a parent to direct the upbringing of a child." ${ }^{289}$ The bill stated the following findings:

(1) the Supreme Court has regarded the right of parents to direct the upbringing of their children as a fundamental right implicit in the concept of ordered liberty within the 14th amendment to the Constitution of the United States ...;

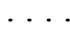

(4) some decisions of federal and state courts have treated the right of parents not as a fundamental right but as a nonfundamental right, resulting in an improper standard of judicial review being applied to government conduct that adversely affects parental rights and prerogatives;

286. Martha Albertson Fineman, What Place for Family Privacy?, 67 GeO. WASH. L. Rev. 1207, 1216-17 (1999) (arguing that while there is a necessity for privacy with regard to family formation and functioning, "hidden beneath the cloak of privacy are power imbalances, perhaps even incentives for the strong to prey upon or exploit the weak. ... Therefore, the obvious goal should be to reconcile both concerns and balance family privacy with protection for family members."); see also generally FINEMAN \& MYKITIUK, supra note 1, at 3 (exploring "what it has meant to develop theory and practice around 'the battered woman,' 'the rape victim,' and 'the cycle of violence'").

287. Woodhouse, supra note 1, at 401 (referencing "traditional theory of parents' rights as God given or natural rights").

288. See generally id. at 396-97 (examining proposed federal Parental Rights and Responsibilities Act of 1995)

289. Id. at 424 app. A. 
(6) governments should not interfere in the decisions and actions of parents without compelling justification ... 290

The bill would have prohibited government interference with a parent's right to direct the upbringing of his or her child unless "the interference or usurpation is essential to accomplish a compelling governmental interest and is narrowly drawn or applied in a manner that is the least restrictive means of accomplishing the compelling interest."291 Although neither the House nor Senate bill ever became law, their proposals indicate the continuing importance parental rights have in American society. Moreover, according to the bills' supporters, similar legislation was proposed in half of the states. ${ }^{292}$

\section{B. Methods to Encourage Limited Interaction with Governmental Officials Without Violating Privacy Rights}

If it is true that Americans are unwilling to have their privacy rights curtailed or eliminated, then solutions must be explored that respect privacy rights. The Fourth Amendment protection against unreasonable search and seizure makes it difficult for anyone else to observe suspicious circumstances or behavior that would alert government officials to a potentially abusive or unhealthy situation. If people are physically isolated and limit or avoid contact with those outside of their home or community, then there may be no way for anyone to give the government sufficient reason to investigate, much less invade private property to determine whether laws have been broken or the rights of a resident have been violated. Overcoming these obstacles without infringing upon privacy rights is challenging but not impossible.

\section{Interaction with Children Through the Education System}

One means of preventing oppression without violating the privacy of individuals is by ensuring some face-to-face interaction between government agents and private citizens, particularly children. One such interaction could take place in connection with compulsory education requirements. Every state constitution includes language requiring the state to establish and maintain a system of free public education. ${ }^{293}$

290. Parental Rights and Responsibilities Act of 1995, H.R. 1946, 104th Cong. § 2.

291. Id. §5.

292. Woodhouse, supra note 1, at 399.

293. Yuracko, supra note 216, at 135. 
Children in public schools have a great deal of interaction with the government because teachers and administrators are all government employees. These employees are required by law to keep detailed records about the progress of each child and notify law enforcement if abuse or neglect is suspected. ${ }^{294}$

The right to have a child educated in a private school is protected by the U.S. Constitution. ${ }^{295}$ These schools provide a greater degree of isolation and privacy than public schools, but states have the right to oversee the curriculum in such schools. ${ }^{296}$ Moreover, there may be at least some interaction with children outside of the child's immediate family, although, the school may be comprised of children from families with the same beliefs and thereby still be relatively isolated from the larger community. Additionally, there may be little regulation of private schools. ${ }^{297}$ However, teachers and other private school employees may be required by law to report suspected child abuse or neglect. ${ }^{298}$

The children most likely to be completely isolated are those who are taught at home. Every state allows home schooling, although the degree of regulation of home-school programs varies widely. ${ }^{299}$ In states such as Texas, students are allowed to be home schooled if the parent or guardian asserts that they are pursuing, in a bona fide (good faith, not sham or subterfuge) manner, a curriculum designed to meet the basic goals of reading, spelling, grammar, mathematics, and a study of good citizenship. $^{300}$ The statute does not provide for any evaluation or

294. "All fifty states and the District of Columbia have child abuse laws in place that require certain persons to report suspected child abuse. Those held accountable include school teachers, school employees, and school authorities." Jason P. Nance \& Philip T.K. Daniel, Protecting Students From Abuse: Public School District Liability for Student Sexual Abuse Under State Child Abuse Reporting Laws, 36 J.L. \& EDUC. 33, 35 (2007).

295. Pierce v. Soc'y of the Sisters of the Holy Names of Jesus \& Mary, 268 U.S. 510, 534-35 (1925).

296. Meyer v. Nebraska, 262 U.S. 390, 402 (1923).

297. For example, Pennsylvania gives private schools the option of being licensed but does not require licensure. 24 PA. CONS. STAT. ANN. $\S 6705$ (West 2006). If a private school chooses to be licensed, it must permit the school board and its representatives to "inspect the school or classes and make[] available to the board, at any time when requested to do so, full information pertaining to the operation of the school." Id. $\S 6712$. If licensure is not sought, the board does not appear to have the authority to conduct such inspections. See id. Similarly, Utah has regulations governing when a private school may enroll a scholarship student, but no other regulations targeting private schools. UTAH CODE ANN. § 53A-1a-805 (West Supp. 2009).

298. See, e.g., CAL. PENAL CODE $\S \S 11165-11166$ (stating that teachers and teacher's aides in public and private schools have a duty to report suspected child abuse or neglect); UTAH CODE ANN. § 53A-6-502 (West 2004) (defining "educators" to include private school teachers, employees, and volunteers, and requiring such educators to report suspected physical or sexual abuse).

299. Yuracko, supra note 216, at 124.

300. Tex. Educ. Code AnN. $§ 25.086$ (Vernon Supp. 2009); Tex. Educ. Agency v. Leeper, 893 S.W.2d 432, 439 (Tex. 1944). 
confirmation of the home-school curriculum or the progress of students being home schooled. ${ }^{301}$ However, the Texas Supreme Court noted:

[T] he TEA [(Texas Education Agency)] is not precluded from requesting evidence of achievement test results in determining whether children are being taught in a bona fide manner. While administration of such tests cannot be a prerequisite to exception from the compulsory attendance law, we do not preclude the TEA from giving this factor heavy weight. 302

However, currently there is neither a mechanism in place to ensure that whatever curriculum the parents adopt is effective, nor a mandate that the TEA set guidelines for home-school evaluations. Achievement tests are not required and, if they are given, there are no guidelines in place regarding the administration of the tests or consequences if students are not progressing.

Other states impose much stricter regulations on parents who choose to home school their children. For example, in Pennsylvania, parents must file a notarized affidavit stating their intention to commence a home-education program and that the program complies with the requirements of the home-education statute by the first of August. ${ }^{303}$ The statute also specifies the number of days and hours per year of instruction that the child must receive and lists the courses that must be taught. ${ }^{304}$

301. See Tex. Educ. Code AnN. § 25.086.

302. Leeper, 893 S.W.2d at 444.

303. 24 PA. CONS. StaT. ANN. § 13-1327.1(b)(1) (West 2006). The affidavit must also include the name of the person responsible for providing instruction, the name and age of each child in the home education program, and the address and telephone number of the home education program site. Id. Moreover, the affidavit must state that required subjects will be taught in English and must include an outline of proposed education objectives by subject area. Id. Additionally, the parent must provide evidence that the child has received the required immunizations and has received the health and medical services required for students of the child's age or grade level. Id. Finally, the affidavit must certify that no adult living in the home or having custody of a child in the home education program has been convicted of certain criminal offenses within the prior five years. Id.

304. Id. § 13-1327.1. The statute reads as follows:

(c) A child who is enrolled in a home education program and whose education is therefore under the direct supervision of his parent, guardian or other person having legal custody shall be deemed to have met the requirements of section 1327 if that home education program provides a minimum of one hundred eighty (180) days of instruction or nine hundred (900) hours of instruction per year at the elementary level, or nine hundred ninety (990) hours per year at the secondary level:

(1) At the elementary school level, the following courses shall be taught: English, to include spelling, reading and writing; arithmetic; science; geography; history of the United States and Pennsylvania; civics; safety education, including regular and continuous instruction in the dangers and prevention of fires; health and physiology; physical education; music; and art.

(2) At the secondary school level, the following courses shall be taught: English, to 
The Pennsylvania statute also provides for significant oversight of the home-education program and evaluation of the home-educated child's progress:

In order to demonstrate that appropriate education is occurring, the supervisor of the home education program shall provide and maintain on file the following documentation for each student enrolled in the home education program:

(1) A portfolio of records and materials. The portfolio shall consist of a log, made contemporaneously with the instruction, which designates by title the reading materials used, samples of any writings, worksheets, workbooks or creative materials used or developed by the student and in grades three, five and eight results of nationally normed standardized achievement tests in reading/language arts and mathematics or the results of Statewide tests administered in these grade levels. ...

(2) An annual written evaluation of the student's educational progress as determined by a licensed clinical or school psychologist or a teacher certified by the Commonwealth or by a nonpublic school teacher or administrator. . . The evaluation shall also be based on an interview of the child and a review of the portfolio required in clause (1) and shall certify whether or not an appropriate education is occurring. At the request of the supervisor, persons with other qualifications may conduct the evaluation with the prior consent of the district of residence superintendent. In no event shall the evaluator be the supervisor or their spouse. ${ }^{30}$

include language, literature, speech and composition; science; geography; social studies, to include civics, world history, history of the United States and Pennsylvania; mathematics, to include general mathematics, algebra and geometry; art; music; physical education; health; and safety education, including regular and continuous instruction in the dangers and prevention of fires. Such courses of study may include, at the discretion of the supervisor of the home education program, economics; biology; chemistry; foreign languages; trigonometry; or other age-appropriate courses as contained in Chapter 5 (Curriculum Requirements) of the State Board of Education.

(d) The following minimum courses in grades nine through twelve are established as a requirement for graduation in a home education program:

(1) Four years of English.

(2) Three years of mathematics.

(3) Three years of science.

(4) Three years of social studies.

(5) Two years of arts and humanities.

Id. § 13-1327.1(c)-(d).

305. Id. § 13-1327.1(e). 
The documentation described above must be submitted to the school district superintendent at the end of the public school year. ${ }^{306}$

If the superintendent reviews the documentation and concludes "that appropriate education is not taking place for the child in the home education program," the superintendent must send a certified letter to the supervisor of the home-education program stating his or her opinion and "specifying what aspect or aspects of the documentation are inadequate." 307 The home-education supervisor has twenty days from receipt of the letter to submit additional documentation establishing that the child is receiving an appropriate education. ${ }^{308}$ If the additional documentation fails to convince the superintendent that appropriate education is taking place, the school board will arrange for a hearing to be conducted by an impartial hearing examiner. ${ }^{309}$ Under certain circumstances the hearing examiner may place the child in public school:

If the hearing examiner finds that the documentation does not indicate that appropriate education is taking place in the home education program, the home education program for the child shall be out of compliance with the requirements of [the home education statute], and the student shall be promptly enrolled in the public school district of residence or a nonpublic school or a licensed private academic school. $^{310}$

Neither the home-education supervisor nor his or her spouse is eligible to supervise the home education for a child for a period of twelve months after that child's home-education program is determined to be out of compliance with the home-education statute. ${ }^{311}$

a. Constitutional Challenges to Home-Schooling Statutes that Allow for or Require Ongoing Evaluation and Oversight of Home-Schooling Programs

Constitutional challenges to statutes such as Pennsylvania's generally have not been successful. In Combs v. Homer-Center School District, parents alleged that the reporting and review requirements of Pennsylvania's compulsory education law violated their religious beliefs

306. Id. § 13-1327.1(h)

307. Id. § 13-1327.1(i).

308. Id. § 13-1327.1(j).

309. Id. § 13-1327.1(k)

310. Id. § 13-1327.1(1).

311. Id. § 13-1327.1(m). 
and their fundamental right to direct the schooling and upbringing of their children. ${ }^{312}$ The Third Circuit Court of Appeals refused to review Pennsylvania's education law under strict scrutiny and instead applied rational-basis review to determine that the law's disclosure and review requirements rationally furthered legitimate state interests. ${ }^{313}$ The parents alternatively claimed that the Supreme Court's ruling in Wisconsin v. Yoder ${ }^{314}$ applied to their claim. ${ }^{315}$ The court of appeals distinguished Yoder, noting that the compulsory education requirements sought to be imposed on the Amish plaintiffs in Yoder threatened their "entire mode of life," while here the Pennsylvania requirements did not pose such a risk. ${ }^{316}$

Similar challenges in other states have also been defeated. In Murphy v. Arkansas, the Eighth Circuit Court of Appeals upheld the constitutionality of the Arkansas Home School Act after a homeschooling couple alleged the Act deprived them of their right to the free exercise of religion, due process of law, equal protection of the laws, and privacy and parental liberty. ${ }^{317}$ The Arkansas Home School Act required home-schooling parents to notify their local school district and provide "the name, age, and grade of each student, the core curriculum to be offered, the schedule of instruction and the qualifications of the person teaching." ${ }^{318}$ The Act also required parents to submit each child to a standardized achievement test each year, which the parents would choose from an approved list, and to a minimum performance test when the child reached age fourteen. ${ }^{319}$ The court found that the state's compelling interest in the education of its children would not be sufficiently safeguarded by parental testing and progress reporting, that the Act passed rational basis scrutiny, and that the right of privacy did not give parents the right to make educational decisions for their children unfettered by reasonable governmental regulation. ${ }^{320}$

In Duro v. District Attorney, Second Judicial District of North Carolina, the Fourth Circuit Court of Appeals found that North Carolina's interest in compulsory education was sufficient to override the

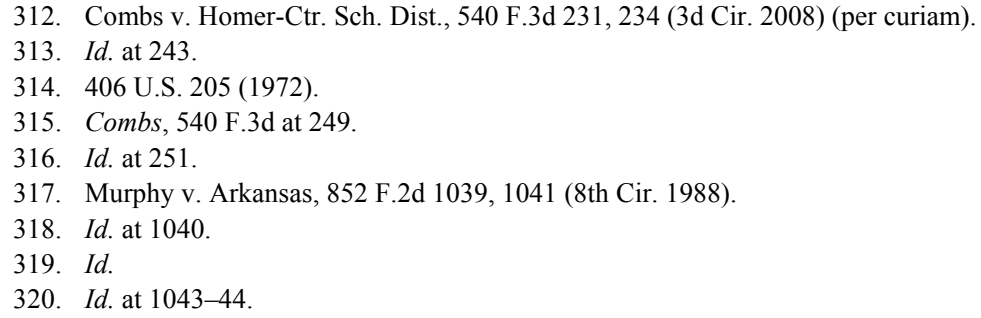


religious interest claimed by a home-schooling parent. ${ }^{321}$ In Duro, a father alleged that his rights under the First and Fourteenth Amendments were infringed by North Carolina's compulsory school-attendance law because sending his children to either a public or private school would violate his religious beliefs. ${ }^{322}$ The children in Duro were taught at home by their mother, who had no educational training. ${ }^{323}$ The district court applied Yoder to find that the compulsory education law was unconstitutional as applied to the father. ${ }^{324}$ The court of appeals reversed, noting that the Amish community was uniquely situated and did allow their children to attend public school through eighth grade, while the Duros were not members of such a community and refused to permit their children to attend outside schools at all. ${ }^{325}$ The court found that the father had not demonstrated that home instruction would "prepare his children to be self-sufficient participants in our modern society or enable them to participate intelligently in our political system," which the court found was a compelling interest of the state. ${ }^{326}$

The Riveras were home-schooling parents convicted of failing to provide an annual home-schooling report to their local school district as required by Iowa statute. ${ }^{327}$ The Riveras argued that the reporting requirement violated their free exercise of religion under the First Amendment. ${ }^{328}$ The Iowa Supreme Court disagreed with the Riveras and affirmed their convictions, finding that "the state's interest in assuring quality education for its children was not outweighed by the resulting burden on the parents' religious beliefs" and that "no alternative means to the reporting requirements... would adequately serve the state's purposes ...."329

321. 712 F.2d 96, 96-97 (4th Cir. 1983).

322. $I d$. at 97 .

323. Id.

324. Id.

325. Id. at 98 .

326. Id. at 99 .

327. State v. Rivera, 497 N.W.2d 878, 879-81 (Iowa 1993).

328. Id. at 879 .

329. Id. at 880-81. See also In re Sawyer, 672 P.2d 1093, 1094 Syl. 2 (Kan. 1983) ("[U]naccredited, unplanned, and unscheduled home instruction with an uncertified teacher does not satisfy ... compulsory school attendance law," and law had rational relationship to legitimate state purpose of educating its children); Blount v. Dep't of Educ. \& Cultural Servs., 551 A.2d 1377, 1377 (Me. 1988) ("'P $]$ rior approval requirement did not violate parents' right to free exercise of religion, and state constitution and Equal Protection and Due Process Clauses of U.S. Constitution afforded parents no additional protection beyond that provided by the First Amendment of the U.S. Constitution.”); State v. Schmidt, 505 N.E.2d 627, 627 (Ohio 1987) (requirement that parents "seek approval of local superintendent for their home education program ... reasonably furthers state's interest in education ... and does not infringe upon free exercise of religion"). 
The Michigan Supreme Court has held that a teacher certification requirement does not violate parents' Fourteenth Amendment rights. ${ }^{330}$ In People v. Bennett, home-schooling parents were convicted of four counts of violating the compulsory education law. ${ }^{331}$ The parents argued that the teaching certification requirement of Michigan's guidelines regarding home schooling violated their rights under the Fourteenth Amendment to direct their children's education. ${ }^{332}$ The court held that the parents did not have a fundamental right to direct their children's education free from reasonable regulation, and thus that the parents' asserted right was not subject to strict scrutiny. ${ }^{333}$ Under a minimal scrutiny test, the court found that the parents failed to show that the certified teaching requirement was unreasonable. ${ }^{334}$

\section{b. Successful Challenges to Home-Schooling Statutes}

Some challenges to home-schooling statutes have been successful. However, these challenges tend to focus on statutes that are vague or especially intrusive. Many successful challenges also alleged violations of state law instead of or in addition to federal law. For example, in Brunelle v. Lynn Public Schools, the Massachusetts Supreme Court held that home visits could not be imposed as a condition of approval of parents' home-schooling plans. ${ }^{335}$ Parents proposing to educate their children at home filed suit against a public school district and district officials for a declaratory judgment that the requirement for home visits as a condition of approval of the parents' home-schooling plans violated their rights under Massachusetts law and the Massachusetts Constitution. $^{336}$ The Massachusetts compulsory education law did not mandate home visits but "[gave] local school officials discretion to develop home school approval guidelines." 337 The court noted it had previously held that home-education proposals could be made subject only to "essential" and "reasonable" requirements, and it concluded that home visits were not presumptively essential to Massachusetts's interest

\footnotetext{
330. People v. Bennett, 501 N.W.2d 106, 111-12 (Mich. 1993).

331. Id. at 108 .

332. Id. at $107-08$.

333. Id. at $111-12$.

334. Id. at 117.

335. Brunelle v. Lynn Pub. Schs., 702 N.E.2d 1182, 1187 (Mass. 1998).

336. Id. at $1183-84$

337. Id. at 1185 .
} 
in education and could not be imposed as a condition of approval of parents' plans. ${ }^{338}$

In some states, the wording of the compulsory education statute was deemed too vague to be enforceable against parents who home schooled their children. In State v. Popanz, the defendant was a home-schooling father convicted of violating Wisconsin's compulsory school attendance law. ${ }^{339}$ The Wisconsin Supreme Court held that the phrase "private school" in the Wisconsin statute was impermissibly vague and violated the Fourteenth Amendment of the U.S. Constitution and Article I of the Wisconsin Constitution, as the statute did not define "private school" and left such determination to the sole discretion of the school attendance officer of the district. ${ }^{340}$ Similarly, in Roemhild $v$. State, the defendants were home-schooling parents convicted of violating Georgia's compulsory attendance law. ${ }^{341}$ The Georgia Supreme Court held that the phrase "private school" in the Georgia statute was unconstitutionally vague because it failed to include a definition of "private school" and left such determination to the sole discretion of local officials. ${ }^{342}$

South Carolina has struck down a requirement relating to the qualifications of home-school instructors. In Lawrence v. South Carolina State Board of Education, home-schooling parents brought an action to enjoin enforcement of a South Carolina statute requiring "parents holding only a high school diploma to pass a basic skills examination known as the Education Entrance Examination (EEE) in order to be approved for home schooling." ${ }^{343}$ The South Carolina Supreme Court noted that under Yoder the state has the power to impose only "reasonable standards" on home-schooling programs available as an

338. Id. at 1184 .

339. State v. Popanz, 332 N.W.2d 750, 751-52 (Wis. 1983).

340. Id. at $752,755$.

341. Roemhild v. State, 308 S.E.2d 154, 155-56 (Ga. 1983).

342. Id. at 157. Other states have upheld similarly vague statutes. In Burrow v. State, a father homeschooling his daughter was convicted of violating Arkansas's compulsory school attendance law. Burrow v. State, 669 S.W.2d 441, 442-43 (Ark. 1984). He argued that the statute was unconstitutionally vague because it required attendance at a "public, private or parochial school" but did not define "school." Id. at 443. The Arkansas Supreme Court disagreed, holding that the language of the statute was "clear enough . . . to put [the defendant] on adequate notice that a course of home study would not constitute a school within the meaning of the statute." Id. Likewise, in State v. Moorhead, home schooling parents in Iowa argued that the compulsory attendance law was unconstitutionally vague and violated the Fourteenth Amendment of the U.S. Constitution. 308 N.W. 2d 60, 61-62 (Iowa 1981). The statute exempted students receiving "equivalent instruction by a certified teacher elsewhere" from the compulsory education requirement, and the defendants argued that the statute's failure to define "equivalent instruction" and "certified teacher" rendered the statute unconstitutionally vague. Id. at 62-63. The Iowa Supreme Court disagreed, holding that the statute sufficiently put citizens on notice as to what the statute required. Id. at 64 .

343. Lawrence v. S.C. State Bd. of Educ., 412 S.E.2d 394, 394 (S.C. 1991). 
alternative to compulsory school attendance in order to protect homeschoolers' free exercise of religion. ${ }^{344}$ Here, the court held that the procedures used to test home-school instructors did not meet a standard of reasonableness. ${ }^{345}$

Similarly, the Michigan Supreme Court struck down a teacher certification requirement for home-schooling families. ${ }^{346}$ In People $v$. DeJonge, parents objected to the requirement on the grounds that their religious beliefs prohibited allowing anyone else to teach their children. ${ }^{347}$ The DeJonge parents did not meet the teacher certification requirement, yet at trial, the prosecution never questioned the adequacy of the DeJonges' instruction or the education the children received. ${ }^{348}$ The Michigan Supreme Court ultimately held "that the teacher certification requirement [was] an unconstitutional violation of the Free Exercise Clause of the First Amendment as applied to families whose religious convictions prohibit the use of certified instructors." 349

First, the court noted that a claim that the statute violated the First Amendment's Free Exercise Clause in conjunction with a claimed violation of parents' right to direct their children's education demanded application of strict scrutiny. ${ }^{350}$ The Michigan Supreme Court articulated the strict scrutiny test as the "compelling interest" test with five elements:

(1) whether a defendant's belief, or conduct motivated by belief, is sincerely held;

\footnotetext{
344. Id. at 395 .

345. Id. at 396.

346. People v. DeJonge, 501 N.W.2d 127, 129 (Mich. 1993). In DeJonge, homeschooling parents were convicted of instructing their children without the aid of certified teachers, in violation of Michigan's compulsory education law. Id. at 129-30. The Ottawa Circuit Court affirmed their convictions, and the case was consolidated with another case on appeal. Id. at 130. The court of appeals affirmed both trial court decisions and reaffirmed their convictions on rehearing. Id. On October 17, 1990, in lieu of granting leave to appeal, the Michigan Supreme Court remanded the case to the court of appeals for reconsideration in light of recent United States Supreme Court precedent. $I d$. at 131 . On remand, the court of appeals again affirmed the defendants' convictions.

347. Mark DeJonge testified that Michigan's requirement that all children be taught by certified teachers violates their religious beliefs because the family "believes that scripture... teaches that parents are the ones that are responsible to God for the education of their children. And for us to allow the State to insert [sic] God's Id. at $130 \mathrm{n} .4$ authority, for us to submit to that would be a sin."

348. Id. at 130

349. Id. at 129 .

350. Id. at 134. The court further noted that Michigan's Constitution mandated strict scrutiny under these circumstances as well. Id. at 134 n.27.
} Id. 
(2) whether a defendant's belief, or conduct motivated by belief, is religious in nature;

(3) whether a state regulation imposes a burden on the exercise of such belief or conduct;

(4) whether a compelling state interest justifies the burden imposed upon a defendant's belief or conduct;

(5) whether there is a less obtrusive form of regulation available to the state. $^{351}$

The court held that the first and second elements were met because the DeJonges' beliefs were sincerely held and those beliefs were religiously based. ${ }^{352}$ The court further held that the teacher certification statute imposed a burden on the DeJonges' exercise of their beliefs. ${ }^{353}$ Thus, the third element was met. ${ }^{354}$

The final two elements were the most controversial. The state claimed "a compelling [] interest in ensuring the adequate education of all children." "355 The court acknowledged this interest, but disagreed that this interest was at issue in the case:

The state's interest is not ensuring that the goals of compulsory education are met, because the state does not contest that the DeJonges are succeeding at fulfilling such aims. Rather, the state's interest is simply the certification requirement of the private school act, not the general objectives of compulsory education. The interest the state pursues is the manner of education, not its goals. ${ }^{356}$

Thus, the proper inquiry was whether this interest in upholding the teacher certification requirement was a compelling interest and, if so, whether this interest could be achieved through less obtrusive means. ${ }^{357}$ The court held that the certification requirement was not a compelling interest. ${ }^{358}$ It noted that it was undisputed that the DeJonge children were

\footnotetext{
351. Id. at 135 .

352. Id.

353. Id. at $136-37$.

354. Id.

355. Id. at 138

356. Id. at 139 .

357. Id. at 140 .

358. Id. "[T] he state in the instant case has failed to provide evidence or testimony that supports the argument that the certification requirement is essential to the preservation of its asserted interest." Id.
} 
receiving "more than an adequate education." 359 Moreover, the court noted that few states retained a certification requirement for home schools, with more than twenty states repealing their teacher certification requirements in the prior decade. ${ }^{360}$

Finally, the court noted that even if the state had stated a compelling interest, it had not established that the certification requirement was the least obtrusive means of achieving that interest. ${ }^{361}$ The court noted that monitoring or evaluation by the state could ensure that adequate education is taking place without unduly burdening the DeJonges' religious freedom. ${ }^{362}$ The court held that "the teacher certification requirement is an unconstitutional violation of the Free Exercise Clause of the First Amendment as applied to families whose religious convictions prohibit the use of certified instructors." ${ }^{363}$

\section{c. Proposals for States with Little or No Oversight of Home-School Programs}

States such as Texas, which currently require no oversight or evaluation of home-school programs or the progress of children being home schooled, could require some form of periodic evaluation. If a parent chooses to administer achievement tests, the state could require that some governmental official be present during the testing. Other, more subjective, forms of evaluation could also be employed. For example, children could be interviewed about what they have learned. This could be especially appropriate if a child has a learning disability that would make standardized testing an inaccurate means of evaluating the child's progress. Again, the key would be some face-to-face interaction with a government official who would be able to confirm that the child is learning and the curriculum is being taught. It also allows the official to observe and report any obvious signs of abuse or neglect.

If more stringent evaluation requirements had been in place in Texas, officials might have had a better relationship with the YFZ families, or at least a better understanding of the identities of the children living on the Ranch. Additionally, officials might have noted the pregnancies of the underage girls and thus would have had grounds to investigate and intervene. Moreover, the curriculum is established by state law and

359. Id.

360. Id. at 141

361. Id.

362. Id. at 143 .

363. Id. at 144 . 
every state could include civics or government as required subjects in public, private, and home-school curriculums. ${ }^{364}$ Including these subjects as part of the testing or evaluation process would help ensure that all children graduate with a basic understanding of how the government works and their basic rights under the law.

These suggestions are not intended to discourage or infringe upon parents' rights to educate their children in the manner they deem appropriate. Instead, it is intended to ensure that the parent's choice does not violate the children's rights. Note that steps should be taken to ensure that the privacy of the parents is not unduly violated. Obviously, the rules would not be limited to children of particular religious or political beliefs. No information need be gathered other than that related to the educational progress of the student. It is not intended to be a covert investigation (search or seizure) but merely one way to ensure compliance with compulsory education while having the incidental benefit of giving an opportunity for intervention if necessary.

d. Prohibiting Home Schooling When There is Evidence the Child May

Be in Danger in the Home

The right to home school is not unlimited. Although parents have a due process right to direct their children's education ${ }^{365}$ and the right to free exercise of their religion, ${ }^{366}$ a law that infringes upon a constitutional right may be upheld if the law furthers a compelling governmental interest and is narrowly tailored to meet that end. ${ }^{367}$ One such compelling interest is education. ${ }^{368}$ Consequently, states are entitled to regulate home-school programs and to enforce reasonable requirements if those requirements are narrowly tailored. ${ }^{369}$ If the state can

364. Currently, all states note the need for civics or government as part of a solid education, but it is not a required course in all states. See Charles N. Quigley, Civic Education: Recent History, Current Status, and the Future, 62 ALB. L. REv. 1425, 1425 (1999). "Although a study of state curriculum guidelines will reveal that every state notes the need for civic education, this important part of the student's overall education is seldom given sustained and systematic attention in the kindergarten through twelfth grade curriculum." Id.

365. Prince v. Massachusetts, 321 U.S. 158, 166 (1944).

366. U.S. CONST. amend. I; Prince, 321 U.S. at 166.

367. See, e.g., Roberts v. U.S. Jaycees, 468 U.S. 609, 623 (1984) ("Infringements on [the right to associate] may be justified by regulations adopted to serve compelling state interests ...."); Jonathan L. v. Superior Court, 81 Cal. Rptr. 3d 571, 593 (Cal. Ct. App. 2008) (parents' power may be limited if they will place the child in jeopardy).

368. See Wisconsin v. Yoder, 406 U.S. 205, 213-14 (1972) (“[A] State's interest in universal education ... is not totally free from a balancing process when it impinges on fundamental rights and interests ....").

369. See, e.g., Jonathan L., 81 Cal. Rptr. 3d at 594 (holding that a child's safety is a compelling 
demonstrate that appropriate education is not taking place in the homeschool program, the state should require the parents to send the child to a public or private school.

States may also deny parents the right to home school their children if there is evidence that the child's health or well-being is at risk. ${ }^{370}$ For instance, in Pennsylvania, the affidavit that parents must submit in order to institute a home-education program must include a statement that "the supervisor, all adults living in the home and persons having legal custody of a child or children in a home-education program have not been convicted of the criminal offenses enumerated in [title 24, section 111(e) of the Pennsylvania statutes] within five years immediately preceding the date of the affidavit." ${ }^{371}$ If this requirement is not met, the parent may not institute a home-education program. ${ }^{372}$

At least one California appellate court has held that restricting a parent's right to home school if the child has been declared dependent because of the abuse or neglect of other children in the home is constitutional. $^{373}$ In Jonathan L. v. Superior Court, the court acknowledged that California statutes permit home schooling as a species of private school education. ${ }^{374}$ However, the statutory permission to home school may constitutionally be overridden in order to protect the safety of a child who has been declared dependent. ${ }^{375}$ The two children in Jonathan $L$. were declared dependent due to the known abuse of their siblings. ${ }^{376}$ The children's "attorney sought an order that they be sent to private or public school, rather than educated at home by their mother, so that they would be in regular contact with mandatory reporters of abuse and neglect." 377 The dependency court declined to issue such an order, determining "that parents have an absolute constitutional right to home school their children."

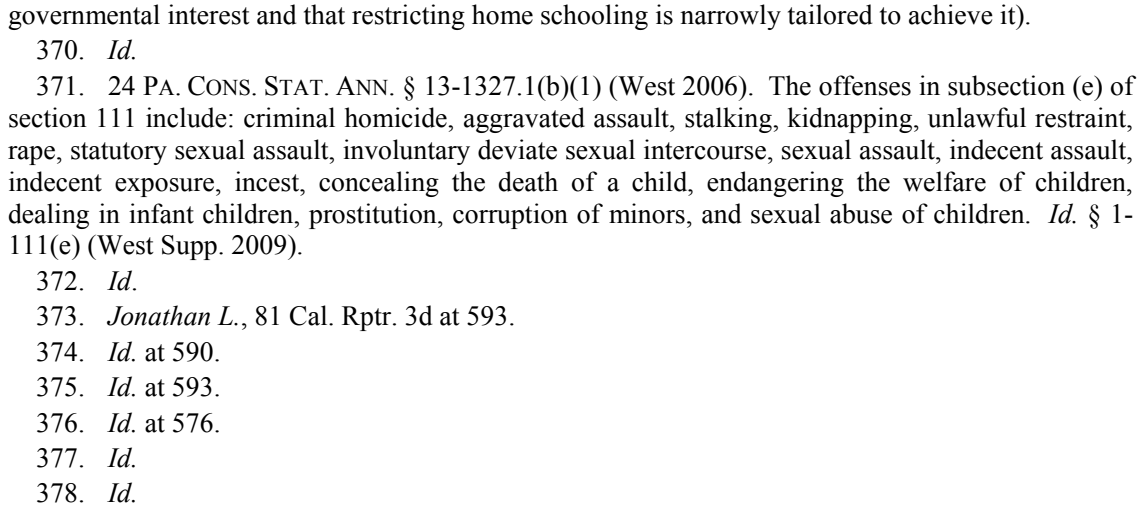


The children's counsel sought relief by a petition for an extraordinary writ to the court of appeal, and the court initially granted the petition on the grounds that California statutory law does not permit home schooling and that such a prohibition did not violate the U.S. Constitution. $^{379}$ The court granted a rehearing in order to provide an opportunity for further argument on the multiple complex issues and to invite a number of governmental and private parties to submit amicus curiae briefs. $^{380}$ The court ultimately decided that the legislature had accepted home schools in California when they were conducted as private schools. ${ }^{381}$

Next, the court considered whether a parent's right to home school his or her children could be overridden to protect the health or safety of the child. ${ }^{382}$ The court acknowledged that United States Supreme Court cases have held that parents have "a liberty interest, protected by the due process clause, in directing the education of their children." "'83 However, it was unclear what level of scrutiny should be applied to restrictions on that right. ${ }^{384}$ The court concluded that it need not decide what level of scrutiny is appropriate since the restriction in question satisfied strict scrutiny and, therefore, would satisfy any lesser test as well. ${ }^{385}$ In applying strict scrutiny, the court noted that the welfare of a child is a compelling state interest. ${ }^{386}$ Moreover, "[t]he United States Supreme Court in Yoder recognized that 'the power of a parent, even when linked to a free exercise claim, may be subject to limitation ... if it appears that parental decisions will jeopardize the health or safety of a child."'

\footnotetext{
379. Id. at 576-77.

380. Id. at 577 .

381. Id. at $577-78$.

382. Id. at 592 .

383. Id.

384. Id. Early cases applied a rational basis test while more recent cases have indicated that strict scrutiny would be appropriate. Id.

385. Id. at 593.

386. Id.

387. Id. (quoting Wisconsin v. Yoder, 406 U.S. 205, 233-34 (1972)). See also Cassady v. Signorelli, 56 Cal. Rptr. 2d 545, 549 (Cal. Ct. App. 1996) (holding that trial court had discretion to order custodial parent to send child to an appropriate public, private, or parochial school, rather than homeschool, in light of trial court's determinations that mother had difficulty coping with the stresses and pressures of life, had questionable decision-making ability, and had "delusional quality in her thinking"); Sloand v. Sloand, 816 N.Y.S.2d 603, 605 (N.Y. App. Div. 2006) (modification of custody order, pursuant to which mother had sole custody of child, to grant father custody of child, was in child's best interests; mother, who suffered from either schizotypal personality disorder or undifferentiated schizophrenia, intended to home school child, although she lacked teaching experience, had not had full-time employment for many years, and had failed to respect child's educational requirements, such as regular and punctual attendance).
} 
But even the compelling state interest will not justify a restriction unless the restriction is narrowly tailored to meet that interest. ${ }^{388}$ In Jonathan L., the restriction at issue was a court order preventing the parents from home schooling their children and instead requiring the children to attend public or private school where the teachers were required to report suspected abuse or neglect. ${ }^{389}$ The court concluded that such an order was narrowly tailored to achieve the goal of protecting children. ${ }^{390}$ "Without contact with mandated reporters, it may well be that the child's safety cannot be guaranteed without removing the child from the parents' custody.... As such, the restriction on home schooling would be the least restrictive means of achieving the goal of protecting the children ...."391

The Jonathan L. case is significant not only because it acknowledges limits on parents' constitutional right to home school their children, but also because it approves of using schools to provide governmental officials access to children in a way that allows the government to protect the children from abuse and neglect. This acknowledgment that home schooling can isolate children and hide evidence of abuse and the additional recognition that contact with people who have the ability and obligation to report signs of abuse or neglect is sometimes necessary even if it interferes with the privacy rights of the parents. The case provides guidance and support for attempts to strike the proper balance between privacy rights of parents and the right of children to live free of abuse or neglect.

\section{Community Outreach and Education}

While there are many programs that provide assistance and support to victims of abuse (particularly women and children), people living in isolated communities may not have access to those programs or even know of their existence. For example, those who grew up in polygamous communities may have such limited contact with the rest of society that they may not even be aware of their rights, much less how to enforce those rights. Worse, law enforcement in some communities may be

388. Jonathan L., 81 Cal. Rptr. 3 d at 593 .

389. Id. at $576 \mathrm{n} .2$ (teachers and teacher's aides in public and private schools are required by law to report suspected child abuse or neglect).

390. Id. at 594 .

391. Id. The court was careful to note that the children in that case had already been declared dependent because of the abuse of their siblings. Id. at 593-94. "We are therefore not concerned with the interference with the rights of a fit parent; the parents in dependency have been judicially determined not to be fit." Id. at 594. 
sympathetic to or active participants in the oppressive culture. Programs addressing the specific needs of individuals in those isolated communities must be developed and supported.

The Arizona and Utah Attorneys General created one program - the Safety Net Program - in 2003. ${ }^{392}$ The Utah Legislature funded the Program, and the money was used to create a non-profit family support center for members of Utah's polygamous communities suffering from abuse. $^{393}$ The Program coordinates resources to help victims of child abuse and domestic violence and holds monthly meetings for representatives from law enforcement, state and local social service agencies, advocacy groups, and members of the community. ${ }^{394}$ The Program created the Safety Net Directory, a list of government agencies, social service providers, and non-profit organizations that provide law enforcement or social services in the area. ${ }^{395}$ The Program also created a manual that provides basic information about polygamous communities to assist human services professionals, law enforcement officers, and others in helping victims from these communities. ${ }^{396}$ Texas is also currently considering implementing a Safety Net Program. ${ }^{397}$

While the Program provides much needed resources, it may not reach victims inside of isolated communities. Those who are not allowed to venture outside of their community alone or who are monitored closely by those who seek to keep them isolated and oppressed may not know that help is available or may not have any way of reaching out to access that help. To that end, widespread advertising, including on television, radio, and the Internet may reach the widest possible audience, although even those efforts will be futile if access to outside news and information is restricted or prohibited.

392. Ben Winslow, 'Safety Net' for Polygamists is Tested, DeSERET Morning News (Salt Lake City, Utah), Apr. 14, 2008.

393. Ben Winslow, Safety Net's New Chief Seeks Balance in Work with Polygamists, DeSERET MoRning News (Salt Lake City, Utah), June 10, 2008.

394. Arizona Attorney General Terry Goddard, Colorado City/Polygamy, http://www.azag.gov /victims_rights/polygamy.html (last visited Mar. 6, 2009).

395. Id.

396. Id.

397. Ben Winslow, Coalition Wants Polygamy 'Safety Net' for Texas, DeSERET MoRning News (Salt Lake City, Utah), Sept. 25, 2008. 
3. Enforcing Laws Mandating Registration of Birth and Identification of Parents

Government should enforce laws making it a crime to fail to register or to lie about parental identity. This will enable law enforcement to track children who do not attend public schools or otherwise participate in society. If authorities do not know that such children exist, they cannot enforce rules such as those regulating vaccination and education. If abuse is alleged, it can avoid the situation that existed in the YFZ case in which authorities could not even identify children or their parents for purposes of evaluating the abuse allegations.

\section{VIII.CONCLUSION}

The right to make certain decisions regarding our bodies, our families, and our religious practices is an essential part of our identity as Americans. The right of privacy in these very personal areas will not be abridged without a fight and should not be abridged except in the most extraordinary circumstances. However, the right to privacy cannot be used to shield abusers and other oppressors from liability or punishment. Nor should privacy laws prevent victims from seeking or obtaining the help they need or the enjoyment of rights they are guaranteed under the law. Government, including legislators and courts, should find ways to balance the privacy rights of all with the need to protect those who are oppressed. It may not be possible to save everyone, but the attempt must be made, because it is possible to save some. 